\title{
Structural Analysis of Oligosaccharides by Nuclear Magnetic Resonance Method
}

\author{
核磁気共鳴法を用いたオリゴ糖の構造解析
}

\author{
Kajihara, Yasuhiro; and Sato, Hajime* \\ Graduate School of Integrated Science, Yokohama City University, 22-2, Seto, Kanazawa-ku, Yokohama, Kanagawa 236-0027, Japan \\ FAX:81-45-787-2413, E-mail:kajihara@yokohama-cu.ac.jp \\ *Bruker BioSpin K.K., 3-21-5, Ninomiya, Tsukuba, 305-0051, Japan \\ Fax:81-298-58-0322, E-mail: hajime.sato@bruker-biospin.jp
}

Key Words:conformation, NMR, NOE, oligosaccharide, pulse program

\begin{abstract}
This review describes several NMR (Nuclear Magnetic Resonance) methods for analyzing the structure of oligosaccharides in addition to technical points such as assignment of all ${ }^{1} \mathrm{H}$ NMR signals, NOE experiments, and modification of pulse programs.
\end{abstract}

要 約

本レビューでは、NMR を用いた糖鎖の構造解析法として、 糖鎖を構成する各糖残基の ${ }^{1} \mathrm{H}$ シグナルの帰属、NOE の実験、 およびパルスプログラムの構築法等について紹介する。

\section{A. Introduction}

Recently, structural analysis of complicated oligosaccharides such as over decasaccharides, can access, because NMR instruments have been developed with many measurement technologies. In addition, synthetic techniques for large oligosaccharides have also been developed. During the synthetic process, organic chemists are able to identify where the glycosidic linkage is formed and to assign the signals step by step in the NMR spectrum. However, it is not easy to perform the assignment of both ${ }^{1} \mathrm{H}$ and ${ }^{13} \mathrm{C}$ signals of deprotected oligosaccharides in an aqueous solution due to heavily overlapped signals in a very narrow region. In this review, we would like to describe the structural analysis of oligosaccharide with advanced measurement methods.

\section{B. Assignment of NMR Signals of Oligosaccharides}

Although protons of protected oligosaccharides by several ester and ether groups are observed as well separated signals due to the inductive effect of protecting groups, sugar ring protons in deprotected oligosaccharides are generally observed between 3-4 ppm. However, anomeric proton signals $(\mathrm{H}-1)$ of those are observed at the low field region of 4.5-5.5 ppm. The coupling pattern and the chemical shift(s) of these H-1's are characteristic dependent on the kind of sugar residues. $\mathrm{H}-1$ of mannose and asparagine-linked $\mathrm{N}$-acetyl- $\beta$-D-glucosaminide are observed in 4.8-5.5 ppm, and that of GlcNAc and galactose are observed in 4.5-4.8 ppm. In addition, the $\mathrm{H}-2$ of mannose and $\mathrm{H}-4$ of galactose have a tendency to be observed at the low field,

\section{A. 序 論}

近年、複雑な構造をもつ糖鎖の解析は、測定法の進歩が NMR 装置の進歩と合いまって容易におこなえるようになった。 また、大型糖鎖の合成技術も進歩してきた。この際、保護基を 利用して糖鎖を合成するので、糖残基間がどのような結合様式 で連結されているかを合成化学者は知ることができ、またシグ ナルの帰属もステップワイズに行うことができる。しかし、脱 保護し合成が完了した糖鎖の ${ }^{1} \mathrm{H}$ や ${ }^{13} \mathrm{C}$ シグナルを $\mathrm{NMR}$ で解析 するようになると、観測されるシグナルが狭い範囲に重なり 合ってくるのでその帰属は困難になる。本ミニレビューでは、 このような問題を解決するために、糖鎖の核磁気共鳴法による 最新の測定法を紹介する。

\section{B. オリゴ糖のシグナルの帰属}

糖鎖を化学合成する際、保護基が結合した段階の糖鎖の NMR シグナルは保護基のインダクティブな効果により多くのシ グナルが分かれて観測されるが、脱保護した糖鎖のシグナルの ほとんどは 3 4 ppm に重なって観測される。幸い、糖のアノ メリックプロトン $(\mathrm{H}-1)$ は、 $4.5 \sim 5 \mathrm{ppm}$ と低磁場領域に観測され る。また、これら H-1 シグナルはその形、および、化学シフト からどのような糖のアノメリックシグナルか判断しやすい特徵 もある。アスパラギン結合型糖鎖 (図1)を例にとると、マンノー ス残基やアスパラギンに結合した N-アセチルグルコサミン残基 の H-1 は 4.8〜5.5 ppm に観測され、その他の N-アセチルグル 
because these protons have an equatorial configuration (Fig.1). As shown in Fig. 2, even ${ }^{1} \mathrm{H}$ NMR spectrum of lactose which consists of Gal- $\beta-1,4-\mathrm{Glc}$, are observed in a very narrow region (3.4-3.9 ppm) . Therefore, it is difficult to perform complete assignment even with the 1-dimensional (1D) ${ }^{1} \mathrm{H}$ NMR spectrum. In the case of 2-dimensional (2D) NMR spectrum such as a DQF-COSY (Double Quantum Filtered COrrelation SpectroscopY) spectrum (1), the correlation signal from $\mathrm{H}-1$ to $\mathrm{H}-2$ can easily assign, but the other correlation signals from $\mathrm{H}-$ 2 to H-6 are difficult to find in the heavily overlapped signals (Fig. 3). In response to this problem, 2D TOCSY (TOtal Correlation SpectroscopY) has much potential as an experimental method (2), which shows correlation signals from H-1 to H-6 along the row and the column of the $2 \mathrm{D}$ spectrum at the resonance of $\mathrm{H}-1$ signals (Fig. 3). In this case, in order to elongate a network of correlation from $\mathrm{H}-1$ to $\mathrm{H}-6$, the coupling constants should exist in the two protons from the $\mathrm{H}-1$ to the $\mathrm{H}-6$ protons. However, several proton signals overlap at the same resonance (chemical shift), and several correlation signals also overlap there. In addition, since digital resolution is low in the 2D NMR, analysis of the peak shape is also difficult. As shown in Fig. 4, pulse sequence of the 2D TOCSY consists of high power 90-
コサミン残基やガラクトース残基の H-1 は 4.5 4.8 ppm に観測 される。また、マンノース残基の 2 位 (H-2) およびガラクトー ス残基の 4 位シグナル (H-4) はエカトリアル配置であることか ら、4.2 ppm 近辺と糖の骨格の ${ }^{1} \mathrm{H}$ シグナルよりも低磁場に観測 される。図 2 に示したラクトースの 1 次元 (1D) NMR ですら環 内プロトンは複雑に重なり合って、その帰属は 1D NMR だけで は困難である。また、図3に示したように、ラクトースの DQFCOSY (二次元Double Quantum Filtered COrrelation SpectroscopY) （1）を用いても、グルコースやガラクトースの H-1 から各 H-2 への相関は容易に見つけることができるが、H-2 から $\mathrm{H}-3 、 \mathrm{H}-$ 3から H-4へとシグナルを追跡するほどその帰属は困難になる。

このような問題を解決するのに容易な測定法として HOHAHA (HOmonuclear HArtman-HArn or TOCSY: TOtal Correlation SpectroscopY)(2) が知られている。この測定法を用いると各糖の H-1 の化学シフトのところから横軸あるいは縦軸方向に沿っ て、カップリングしているシグナルが全て表示される (図3)。 従って、この測定法を利用すると各糖残基の環内でカップリン グしている ${ }^{1} \mathrm{H}$ シグナルの化学シフトが容易に観測できる。し かし、いくつかの ${ }^{1} \mathrm{H}$ シグナルが同じ化学シフト上に観測され る場合は依然帰属が困難である。また、2D スペクトルのデジ夕 ル分析能は 1D スペクトルより低いのでシグナルの形を解析す ることが難しい場合がある。図 4 に、その 2D TOCSY のパル

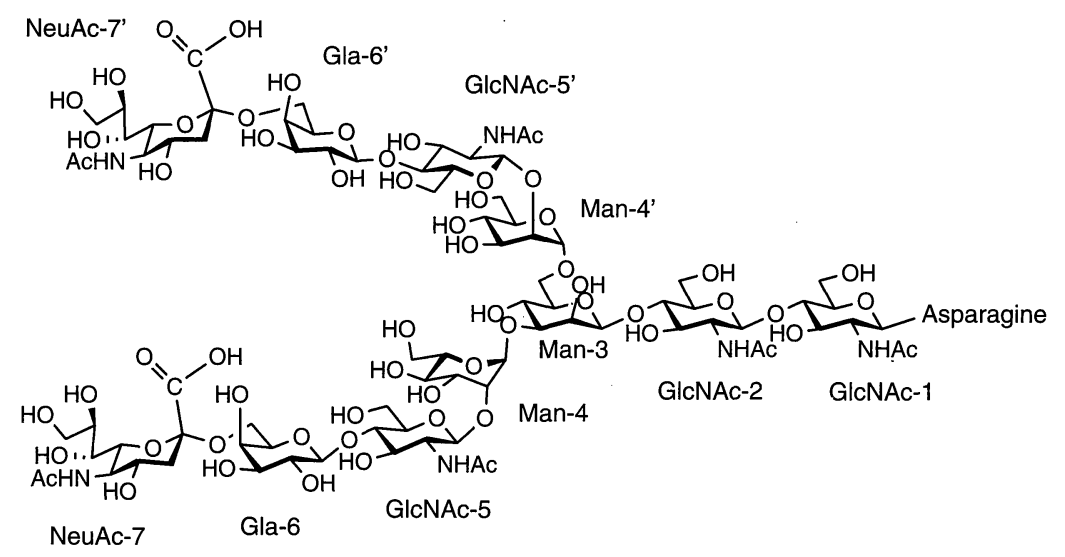

Fig. 1. Structure of asparagine linked oligosacharide.

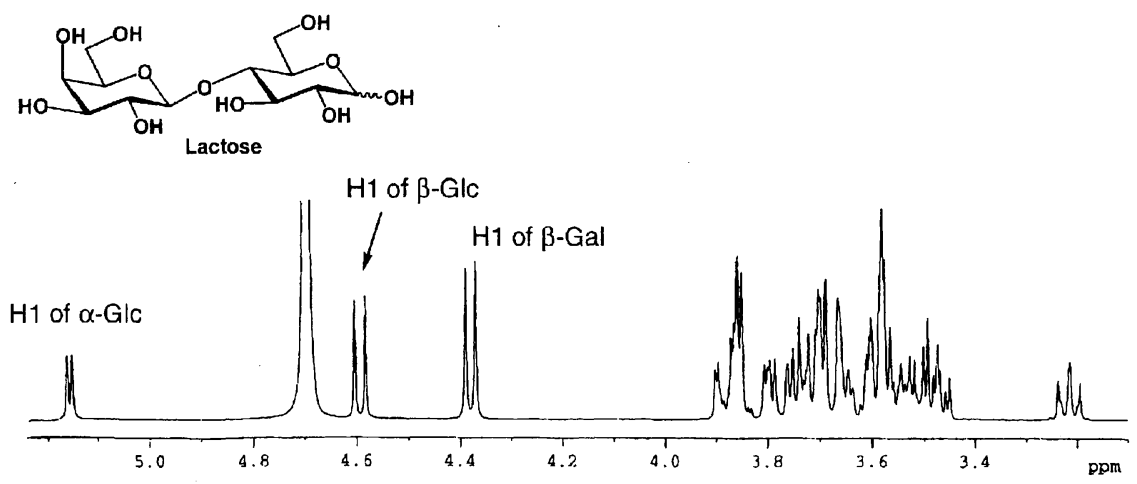

Fig. 2. ${ }^{1} \mathrm{H}$ NMR spectrum of Lactose. 

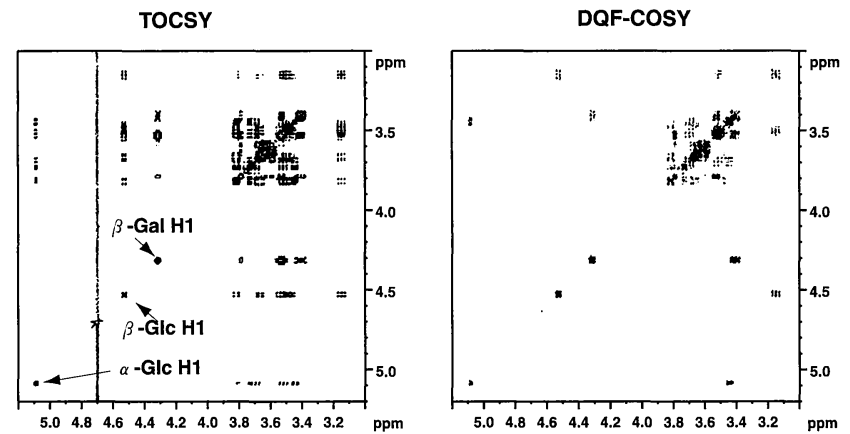

TOCSY (expansion)

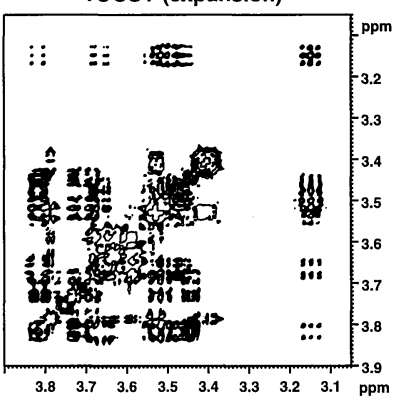

DQF-COSY (expansion)

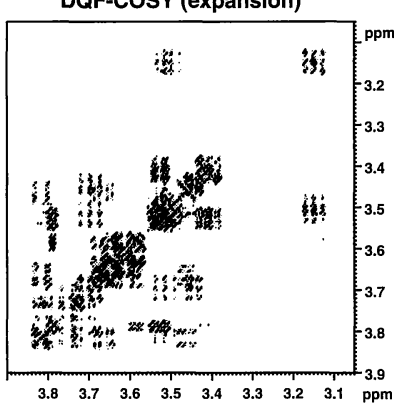

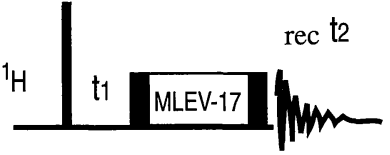

Fig. 4. Pulse sequence of 2D TOCSY.

Fig. 3. Comparison of 2D COSY and TOCSY (Lactose).

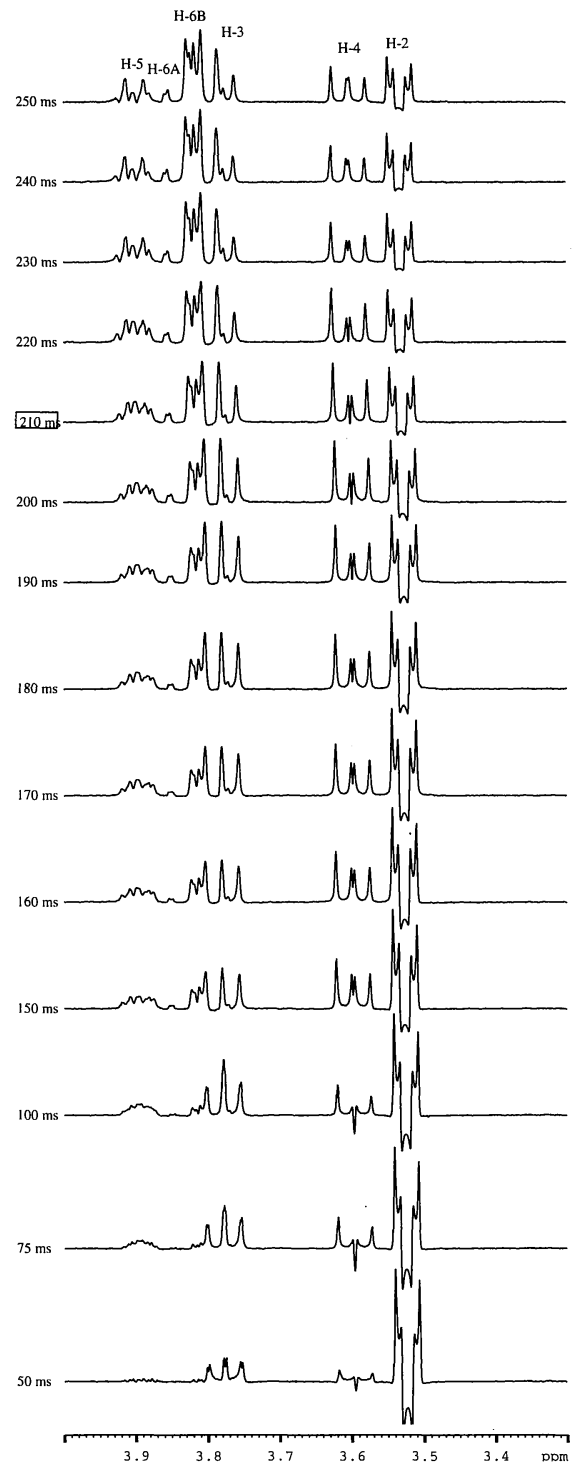

Fig. 5. 1D selective TOCSY dependent on mixing time. The spectra were measured by excitation of the anomeric signal of $\alpha$-glucose in D-lactose. 
degree of rectangular pulse and subsequent spin-locking pulse train (MLEV-17: isotropic mixing time). The first 90-degree pulse is generally set for about 10 -microseconds, which rotates all protons from thermal equilibrium state to transverse axis. Then, the duration of MLEV-17 sequence transfers the magnetization from $\mathrm{H}-1$ to $\mathrm{H}-6$. However, the 2D TOCSY has several drawbacks. Although the 2D TOCSY method can measure almost ${ }^{1} \mathrm{H}-{ }^{1} \mathrm{H}$ networks simultaneously, measurement requires a long experimental time and the digital resolution of the spectrum is low. On the other hand, 1D version of 2D TOCSY can be measured as a high resolution compared to that of 2D TOCSY and the measurement time ranges from a few minutes to an hour. In addition, using varying TOCSY-isotropic mixing times, stepwise observation of correlation signals from H-1 to H-6 can be performed (Fig. 5). In 1985, Prof. Kessler reported potential methods using selective excitation pulses (3), such as gaussian or half-gaussian shape, instead of high power rectangular pulse, and this technique enabled us to perform sophisticated 1D-COSY, 1D-TOCSY, and 1D-NOESY experiments (3).

\section{Selective Excitation}

Before we introduce the characteristic nature of these experiments, we would like to describe the shaped pulses. In the case of general ${ }^{1} \mathrm{H}$ NMR spectrum, the experiment adopts a high power rectangular pulse which can uniformly excite a wide range of $15 \mathrm{ppm}$ (over $6000 \mathrm{~Hz}$ ) (Fig. 6A). Substitution of the rectangular hard pulse in the conventional experiment by a shaped pulse is called selective excitation, or selective experiment. The long duration (ex. 10-200 ms) of the gaussian shaped pulse can reap a single signal (Fig.6B). In other words, we can extract a desired signal from the bulk of ${ }^{1} \mathrm{H}$ signals and this result is equal to extract the magnetization desired from all ${ }^{1} \mathrm{H}$ in the molecular. This magnetization can be used to make multiple pulse experiments, such as 1D-COSY, 1D-TOCSY, and 1D-NOESY. Over 30 kinds of the shapes (Fig. 7) have been reported and are used for selective excitation, inversion for a single signal, adia-
スシーケンスを示した。最初の 90 度パルスは通常 10 マイクロ 秒程度の長さが用いられる。これにより糖鎖の全ての 'H シグナ ルを励起して横磁化をつくる。つぎにMLEV-17 というスピン ロックパルス (Isotropic Mixing Time) により、Jカップリングが あれば H-1 から H-6 まで磁化移動が起こることになる。しか し、この方法は幾つかの欠点をもっている。2D 法は 1 回の実 験で全体像を得ることができるが、1D法に比べて測定時間が長 く、また、分解能が低い。それに対して 1D 法は測定時間が短 く、高分解能である。また、混合時間 (スピンロッキンタイム) の長さに応じて磁化移動の効率が变化することを利用して、あ る ${ }^{1} \mathrm{H}$ から近い ${ }^{1} \mathrm{H}$ だけの相関から遠い ${ }^{1} \mathrm{H}$ までの相関を連続的 に変化させることもできる(図5)。これにより、重なったシグナ ルの帰属がさらに容易になる。1985 年には、有用な測定法が Kessler らによって開発されている (3)。これらは、矩形型パル スをガウシアン波形、 half ガウシアン波形に変えた選択励起パ ルス (=shaped pulse) を用いた1D-COSY、1D-TOCSY、1DNOESYである (3)。

\section{C. 選択励起法}

これら測定法を説明する前に、まず shaped パルスについて 説明することにする。通常の $1 \mathrm{D}^{1} \mathrm{H}$ NMR は、シグナルが観測 されるであろう 0 から $15 \mathrm{ppm}$ を均一に励起できるハードパル ス (矩形型パルス)を用いる (図6A)。一般的な測定法の 90 度矩 形型パルスをシェープドパルスに変えると選択的励起あるいは 選択実験といわれる方法になる。パルス幅を数十ミリ秒から百 数十ミリ秒と長くし、アンプの出力を下げてガウシアン波形を 用いて励起するとある特定の狭い領域(パルス時間の逆数に比 例：単位 $\mathrm{Hz}$ )のシグナルだけ励起することができる(図6B)。言い 換えるとオリジナルの ${ }^{1} \mathrm{H}$ シグナルのうち、任意の'Hシグナルだ け励起することができる。この抽出した磁化は、1D COSYや、 1D TOCSY、1D NOESY などのマルチパルス実験に利用できる。 シェープドパルスは 30 種類以上報告されており(図7)、それら は選択的励起、シグナルの選択的反転、アディアバティックデ

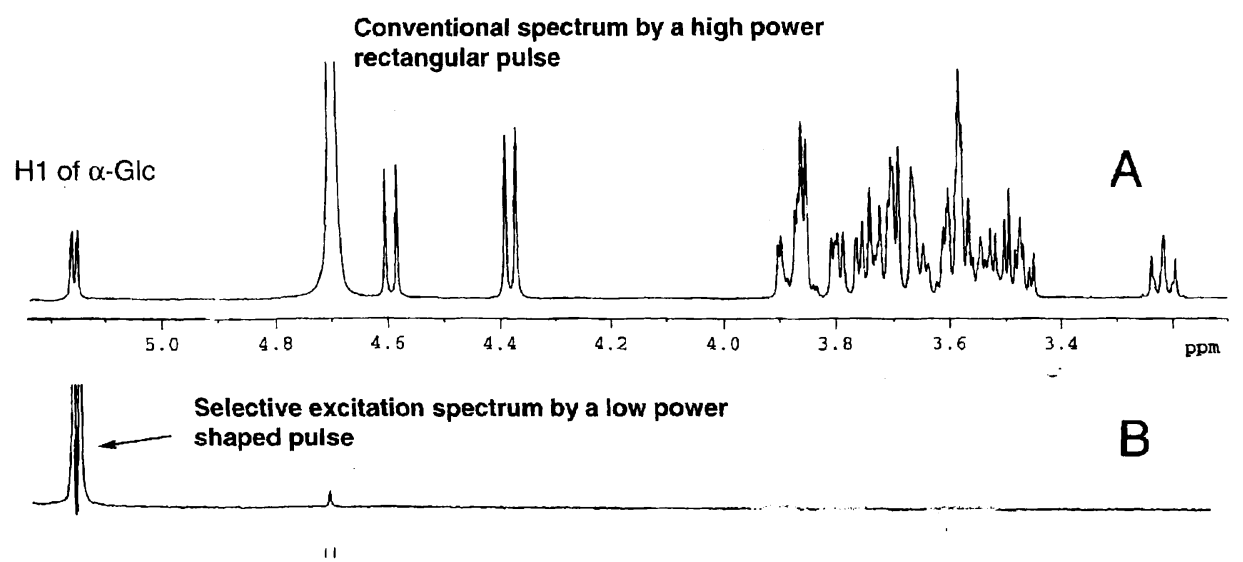

Fig. 6. ${ }^{1} \mathrm{H}$ NMR spectrum of Lactose and its selective excitation of $\mathrm{H1}$ of $\alpha$-Glc. 


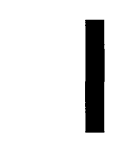

Rectangular

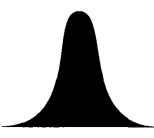

Gaussian

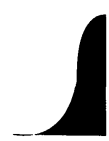

Half Gaussian

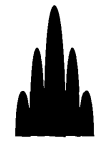

REBURP

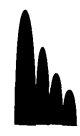

U-BURP

Figure 7. Five examples of shaped pulse.
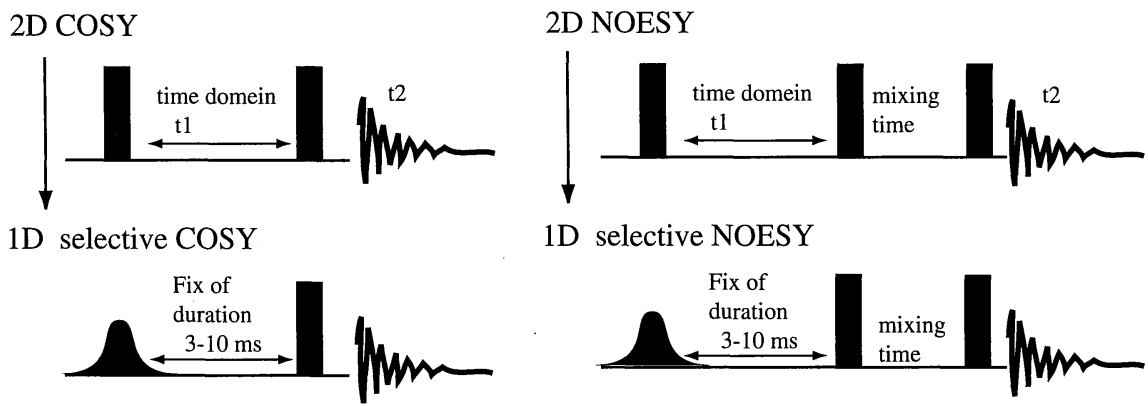

1D selective NOESY
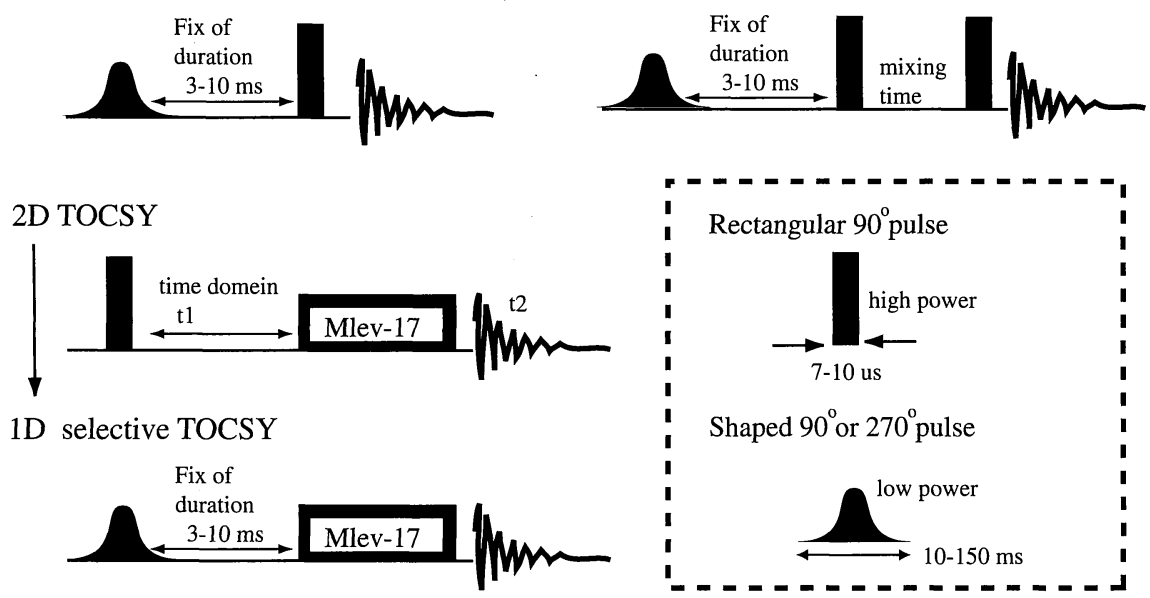

Shaped $90^{\circ}$ or $270^{\circ}$ pulse

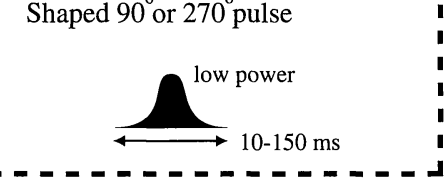

Duration of time domein is a variable delay dependent on the 2D spectrum.

Fig. 8. Modification on 2D pulse sequences to 1D selective experiments.

batic decoupling and refocusing, etc (4). Pulse sequences of 2D experiments adopt nonselective excitation with high power rectangular 90-degree pulse to rotate the magnetization along a transverse axis, which is then treated by a subsequent pulse sequence. Therefore, substitution of the first 90 -degree pulse by a shaped pulse and removal of duration for the time-domain in t1, enable us to acquire 1D multiple pulse experiments such as 1D-COSY, 1D-TOCSY, and 1D-NOESY (Fig.8). These small changes generate a desired 1D multiple pulse experiment. This method is now conventional and used in the structural analysis of oligosaccharides.

The high resolution spectrum obtained by the above 1D experiment corresponds to a slice of a 2D NMR spectrum. In this case, a ${ }^{1} \mathrm{H}$ signal selectively excited corresponds with one of a diagonal signal on the 2D NMR spectrum (Fig. 9). Modern NMR instruments generally equip the system to generate shaped pulses as well as the pulse programs for 1D-TOCSY, -COSY and -NOESY experiments. However, since this experiment requires calibration of the phase difference between the original rectangular and the shaped pulses, operators should be familiar
カップリング、リフォーカシングなどに利用されている (4)。2D 測定のパルスシークエンスは、非選択的な高出力 90 度パルスを 用いて Z 軸方向の磁化を横軸に倒す。そしてこれに対しパルス を続けて発信するように構成されている。したがって 2 次元測 定のパルスシークエンスのうち、最初の 90 度パルスをシェープ ドパルスにかえ、二次元に展開する時間を固定值 (例えば数マイ クロから数ミリ秒)にすれば、1D COSY、1D TOCSY、1D NOESY のような 1 次元マルチパルス実験のパルスシークエン スができる(図8)。これらの簡単な変更で任意の 1D マルチパル ス実験が可能になるとともに、これら測定法は糖鎖の構造分析 の分野で一般的に使うことができる。このような 1 次元高分析 能スペクトルは、2D スペクトルのあるケミカルシフト值を切り 出した $1 \mathrm{D}$ スペクトルに相当する。またこの切り出したスペク トルに関しては、対角ピーク上のシグナルが 1D 実験において 選択的励起したシグナルに相当する(図9)。通常このような シェープドパルスや 1D COSY、1D TOCSY、1D NOESY は近年 販売されている機種では標準的な測定法としてどの機種の NMR にも装備されているので手軽に利用できるようになっている。 この方法は有用であるが、いくつかの短所をもっている。選択 


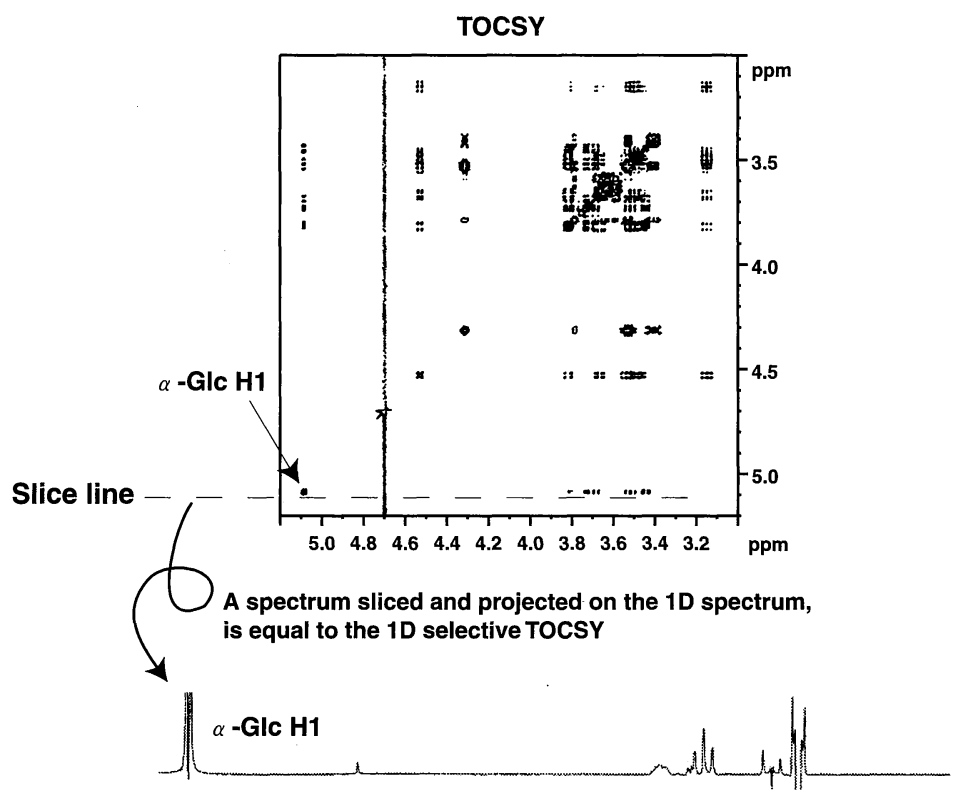

Fig. 9. 2D TOCSY (Lactose) and 1D selective TOCSY.

with the NMR instrument in order to have an excellent NMR spectrum. In addition, since this phase cycle of pulse sequences is not simple, the experiment requires over 8-scanning for the spectrum. In order to solve these drawbacks, the excitation method combined with a rectangular (90-degree), shaped pulse (180-degree) and gradient pulses (5) have been improved as shown in Fig. 10C (6). This excitation method does not require the calibration of the phase difference between the original rectangular (Fig.10B) and shaped pulses (Fig.10A) and is now applied to various experiments. Nevertheless the calibration of the power level for the shaped pulse is not perfect, and unwanted signals are removed by the gradient pulses. In addition, even 1scanning experiment obtains a good spectrum, because the phase cycle for removing unwanted signals and quadrature image, is not essential due to the adoption of coherence selection by the gradient pulses. A coherence diagram is shown in Fig.10C. When all ${ }^{1} \mathrm{H}$ magnetizations of the sample are to be a thermal equilibrium state, the coherence order is " 0 " (state a). After application of 90-degree pulse exciting magnetization of protons to become transverse magnetization (b), coherence order is up to " $+/-1$ ". Toward these states, the gradient pulse (G1) is examined to spoil all transverse magnetization and then subsequent selective 180degree pulse such as RE-BURP (C) can change the coherence order of desired proton, e.g. $+1 \rightarrow-1$ or $-1 \rightarrow+1$. In this case, the coherence order of the other protons which are not inverted by the selective pulse, is not changed. Second gradient pulse (G2) refocuses (or rephases) magnetization of the selected ${ }^{1} \mathrm{H}$ having coherence order II and are then finally observed as FID signals. Since the other protons having coherence order I and IV are now spoiled (these can not resonate with the original Larmor frequency), these protons are not observed due to the huge loss of sensitivity of these protons. In order to deal with
励起 90 度パルスと矩形型ハードパルスとの位相差を求める必要 があるために、NMR 分光器に精通していないと良好なスペクト ルを得られない場合がある。また位相回しが煩雑なため少ない 積算回数で積算できない。そこで、これらの問題を克服するた めに図10の方法が発表され、現在は一般的に用いられている (5)。この方法の特長は選択励起パルスとハードパルスとの位相 差を求める必要がないこと、またパルスのキャリブレーション が不完全な場合でも、不要なシグナル成分はグラジェントパル

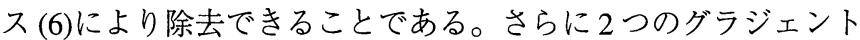
パルスによりコヒーレンスセレクションを行っているので位相 回しの必要がなく、そのため 1 回積算で測定することができ る。図 10Cにコヒーレンスダイアグラムを示す。まず a におい てサンプル分子内の全ての ${ }^{1} \mathrm{H}$ の磁化は熱平衡状態にある。この ときのコヒーレンスオーダーは 0 である。90度パルスで全ての ${ }^{1} \mathrm{H}$ の磁化を励起して横磁化をつくると(b)、コヒーレンスオー

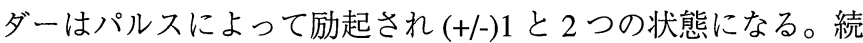
いて 1 つ目のグラジェントパルスにより、全ての ${ }^{1} \mathrm{H}$ の横磁化 をスポイルする(spoil, dephase または defocus とも言う)。ついで 励起したいプロトンのみに、選択励起 180 度パルスを照射する と(c)、その選択励起した ${ }^{1} \mathrm{H}$ のコヒーレンスオーダーのみが変 化し反転する $(+1 \rightarrow-1$ および $-1 \rightarrow+1)$ が、その他の ${ }^{1} \mathrm{H}$ のコヒー レンスオーダーは変化しない。そして2つ目のグラジェントパ ルスにより、コヒーレンスオーダー II または III を有する ${ }^{1} \mathrm{H} の$ み(選択励起したプロトンのみ)が再結像する (rephase または refocus とも言う)。NMR シグナルはコヒーレンスオーダーの-1 を 観測しフーリエ変換しているので、コヒーレンスオーダー II の みが最終的に観測される。コヒーレンスオーダーIおよびIV は スポイルされたまま(装置の共鳴周波数では観測できない状態) 


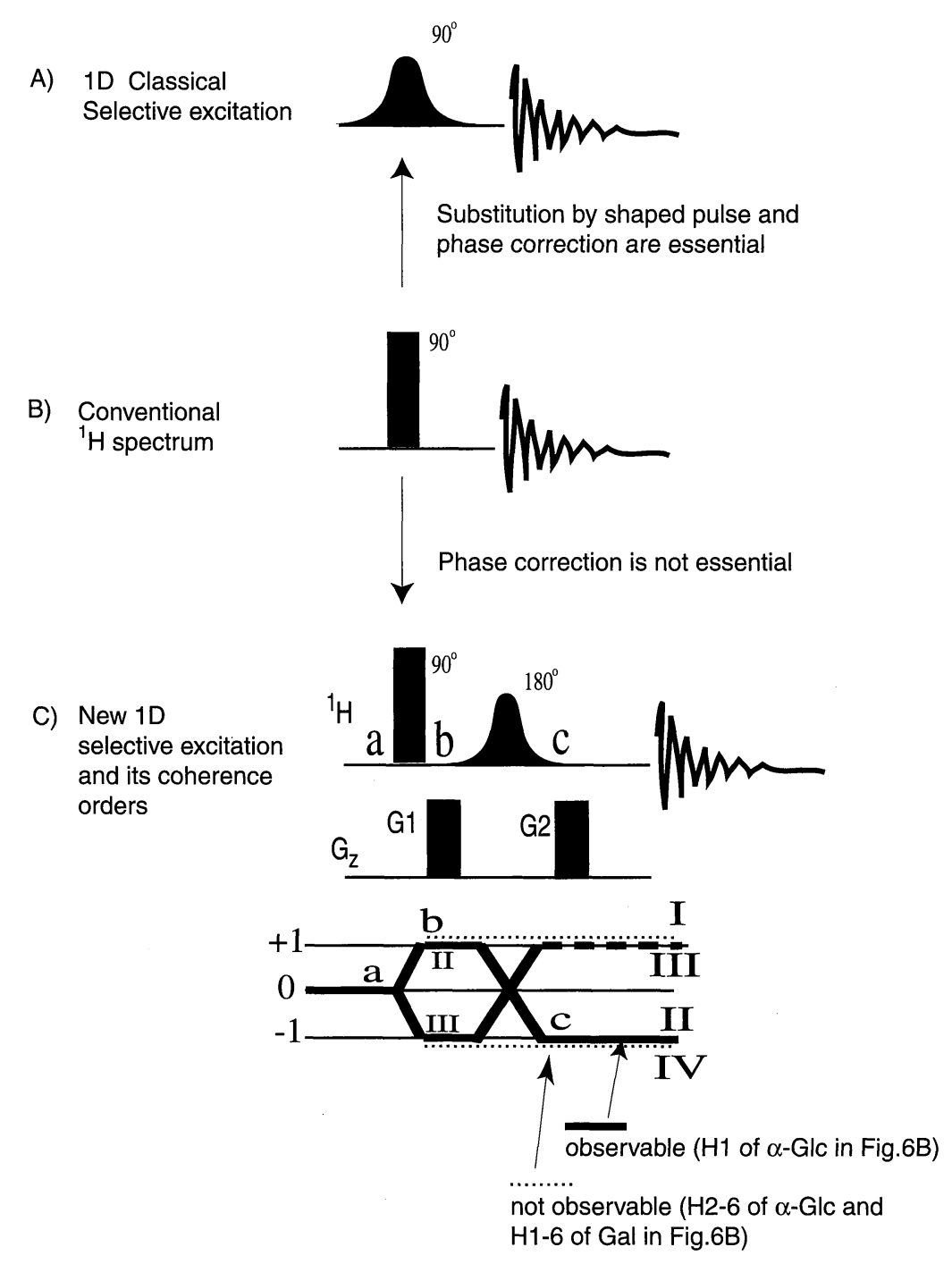

Fig. 10. Pulse sequences of a classical and a new selective excitation. Gz: gradient pulse along $Z$ axis; G1:first gradient pulse; G2:second gradient pulse.

these gradient pulse and coherence order, we should understand the relation " $\Sigma \mathrm{GiPi}=0$ ", where the Gi and Pi are intensity of gradient pulse and coherence order, respectively. The equation means that these protons with a coherence order of -1 , can be observed as an NMR signal when a total value of the product of the gradient pulse and coherence order is " 0 " $(\Sigma \mathrm{GiPi}=0)$. According to the coherence order diagram and pulse sequence shown in Fig.10 C, when G1:G2 ratio is 1:1, coherence orders can be estimated as shown below.

Coherence order II: $1 \times 1+1 \times(-1)=0$ (observable)

Coherence order IV: $1 \times(-1)+1 \times(-1)=-2$ (not observable)

Therefore, this pulse sequence can potentially be used to purge the unwanted signals, which are observed close to the desired excitation signal.

We have described the basic concept of selective pulse,
となり、これらの 'H の NMR 的な感度はほぼゼロとなり観測さ れない。ところでNMR シグナルの観測にはグラジェントパル

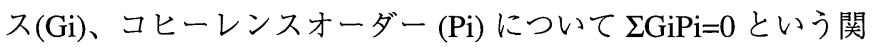
係がある必要となる。すなわちグラジェントパルスの強度とそ のときのコヒーレンスオーダーとの積の総和が、FIDを観測す る際に0であればそのプロトンは観測されることになる。例と して G1:G2=1:1 のとき上述のコヒーレンスオーダーII および IV を検証すると以下のようになる。

$$
\begin{aligned}
\text { コヒーレンスオーダー II: } 1 \times 1+1 \times(-1)=0 \text { (観測される) } \\
\text { IV: } 1 \times(-1)+1 \times(-1)=-2 \text { (観測されない) }
\end{aligned}
$$

このパルスセットを使うことは、選択励起するシグナルの 近くの励起したくないシグナルを消すことができ有効である。

ここまで選択的励起、グラジェントパルスそしてマルチパ 
gradient pulse and multiple pulse experiments, and we would now like to introduce several papers for structural analysis of oligosaccharides.

\section{Structural Analysis of Oligosaccharides}

In the field of structural analysis of oligosaccharides, the valuable database, "reporter group" made by Vliegenthart et al. is widely used to determine the primary oligosaccharide structure (7). This analysis was based on extensive proton decoupling experiments toward the enormous oligosaccharide library obtained from natural sources. In addition, they first used a 3D HMQC-NOESY experiment in the structural analysis of an undecaoligosaccharide (8). In 1990, Sabesan, Duus and Bock first performed a complete structural analysis of GD1a using 1D TOCSY and NOESY including a selective pulse with Gaussian shaped pulse (9). Since GD1a consists of 6 sugar residues (Fig.11), over 40 protons and carbons should be assigned. In this research, all proton signals were extracted and then assigned by 1D TOCSY exciting at each of $\mathrm{H}-1$ signals and $\mathrm{H}-3$ of NeuAc. However, since the selective excitation method using gradient pulse was not established in 1990, they used a classical shaped pulse (Fig. 10A) derived from a large selective excitation unit which is now a small electrical board equipped in any modern instrument as a standard system. The complete assignment method they used is convenient and is now used in several

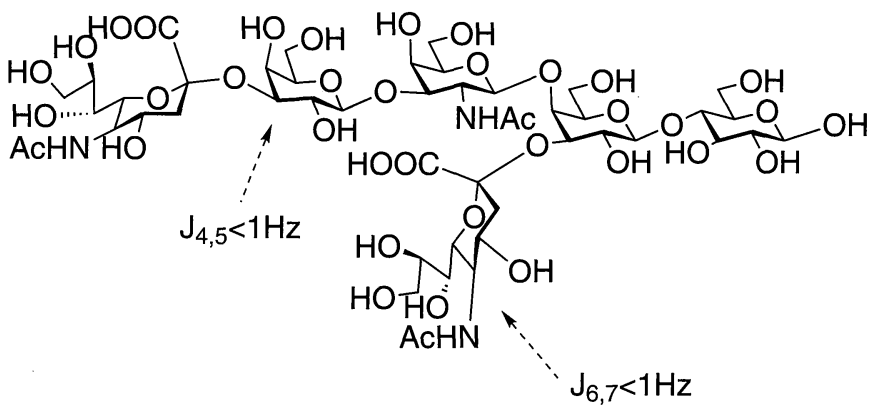

Fig. 11. Structure of GD1a.
ルス実験に関する基本概念を述べたので、ここからは、過去に 報告された糖鎖構造解析の例をいくつか解説する。

\section{D. オリゴ糖の構造解析}

複雑な糖鎖の一次構造解析法としては、Vliegenthart らの reporter group というデータベースが広く利用されている(7)。彼 らは、天然から単離した膨大な種類の糖鎖の NMR を測定し、 その構造の違いに依存した ${ }^{1} \mathrm{H}$ シグナルの化学シフトを調べ非常 に貴重なデータベースを作成している。また、いち早く $3 \mathrm{D}$ HMQC-TOCSY 法を糖鎖構造解析に適用し、複雑な構造をもつ 糖鎖の解析も行っている (8)。1990 年になり Bock, Duus, Sabesan らは、前述のガウシアンシェープドパルスを用いた $1 \mathrm{D}$ TOCSY、1D-NOESY により GD1aのような複雑な構造をもつ糖 鎖の完全解析に初めて成功した (9)。GD1a は 6 残基の糖からな るため (図11)、40 以上の ${ }^{1} \mathrm{H}$ および ${ }^{13} \mathrm{C}$ シグナルの帰属が必要 となる。この研究においては、糖の H-1 およびシアル酸の H-3 を選択励起して 1D TOCSY により全ての ${ }^{1} \mathrm{H}$ を抽出し帰属して いる。このとき用いた選択励起法はグラジュエントパルスを用 いていないもので、当時は選択励起のための大きな excitation 工 ニットをNMR 装置に付属させて測定していた。また現在はこ の選択励起ユニットは内蔵型ボードとなり、多くの装置に標準 的に装備されている。彼らが行った構造解析のストラテジーは 非常に簡便で今現在でも彼らの手法が最も有効と思われる。彼 らは、まず糖鎖を構成する各糖残基の H-1 を励起することで 1DTOCSY を糖残基の数だけ測定し、全ての ${ }^{1} \mathrm{H}$ のシグナルを帰属

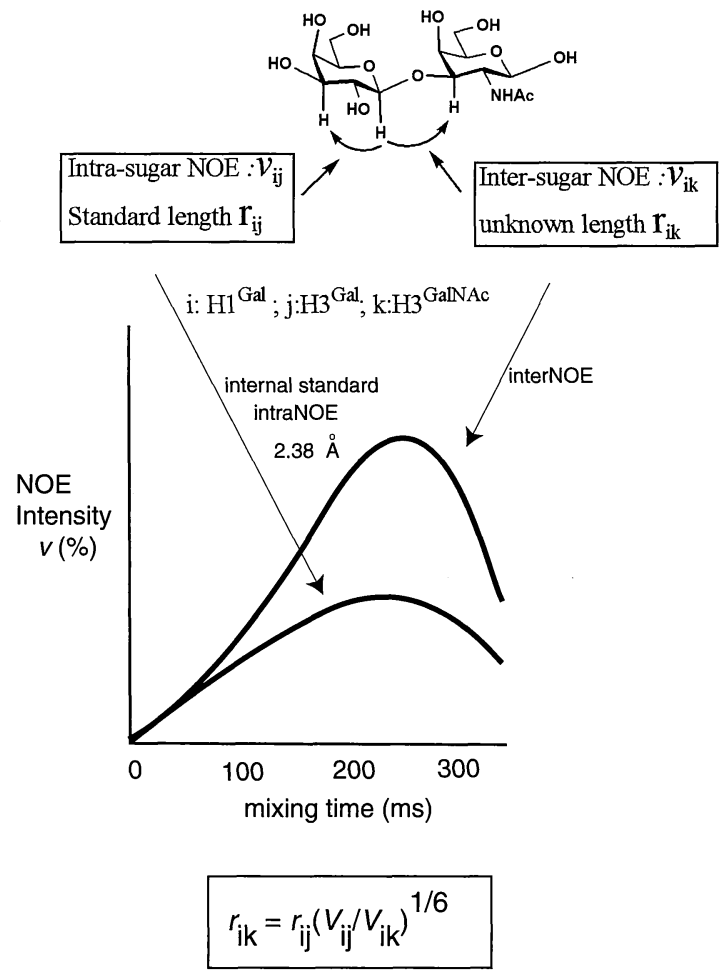

Fig. 12. NOE build-up rate curve and estimation of intersugar proton distance. 
Trends in Glycoscience and Glycotechnology Vol.15 No.84 (July 2003) pp.197-220

oligosaccharide analyses.

However, in the case of sialic acid and galactose, TOCSY development from $\mathrm{H}-1^{\mathrm{Gal}}$ and $\mathrm{H}-3^{\mathrm{NeuAc}}$ stopped at $\mathrm{H}-4^{\mathrm{Gal}}$ and $\mathrm{H}-$ $6^{\mathrm{NeuAc}}$, respectively, due to a small coupling constant (Fig. 11). For these drawbacks in these experiments, the Sabesan group used ${ }^{1} \mathrm{H}^{-13} \mathrm{C}$ correlation and NOE experiment for the assignment of all proton signals. In addition, they performed a conformational analysis of GD1a using the 1D NOESY experiment in which selective excitation pulse was adjusted to the resonance of each of $\mathrm{H}-1$ and $\mathrm{H}-3^{\mathrm{NeuAc}}$. Their build-up rate curve which adopts NOE intensity and mixing times $(0-1 \mathrm{~s})$ to the vertical and the horizontal axis respectively, enabled them to estimate the ${ }^{1} \mathrm{H}^{-1} \mathrm{H}$ distance around each glycosyl linkages (Fig.12). In order to estimate inter sugar ${ }^{1} \mathrm{H}-{ }^{1} \mathrm{H}$ distance by use of intensity of inter sugar NOE, they used intensity of intrasugar NOE e. g. $\mathrm{H}-1$ to $\mathrm{H}-3$ ( $\mathrm{r}_{\mathrm{ij}}=2.38$ angstrom) or H-5 (2.11 angstrom) as a standard length which has been estimated by $\mathrm{X}$-ray analysis.

Using this standard length $r_{i j}$, they estimated the length $\mathrm{r}_{\mathrm{ik}}$ of intersugar ${ }^{1} \mathrm{H}-{ }^{1} \mathrm{H}$ (Fig. 12) (10) and then applied it to the conformational analysis by use of HSEA (Hard-sphere exo anomeric effect calculations) (11).

Hence, they applied their basic techniques to the analysis of binding mode between sialyl-oligosaccharides and both Influenza virus Hemagglutinin (12) and Neuraminidase (13).

Poppe et al. also examined a sophisticated approach to the structural analysis of sialyl LewisX on both free state and binding state to the Selectin (14).

Structural analysis of oligosaccharides on a glycoprotein and glycopeptide has also been performed by several groups. The Danishefsky group examined the structural analysis of glycopeptide having several oligosaccharides on its peptide backbone (15). The Halbeek (16) and Vliegenthart (17) groups also performed complete assignment of oligosaccharide on the peptide. In their case, assignment of all oligosaccharides of glycoforms was also performed. This experiment can extract each anomeric proton signals of sugars by HMQC pulse sequence and then the magnetization was correlated to the each ring proton signal by TOCSY pulse sequence (HMQC-TOCSY). Therefore, sequential assignment of protons from $\mathrm{H}-1$ can be performed by varying the TOCSY-isotropic mixing time. In addition, since there are few correlation signals of protein-carbon around the resonance of anomeric carbons, assignment of the each sugar proton can be examined even when many proton signals are overlapping on the $1 \mathrm{D}^{1} \mathrm{H}$ NMR spectrum. The Bock (18) and Imperiali (19) groups also demonstrated a complete assignment of oligosaccharide on glycopeptide.

Complete assignment of proton signals is essential for the conformational analysis of oligosaccharides using NOE experiments such as phase sensitive 2D NOESY. However, if several proton signals overlap at the same resonance where the NOE signals are observed, assignment of these is difficult. To re-
した。ただ、ガラクトースとシアル酸残基はTOCSYを展開する 際、J 值が $1 \mathrm{~Hz}$ 以下のところがあるために TOCSY 展開が停止 し、ガラクトースの場合は H-1 から H-4 まで、シアル酸の場合 はH-3 から H-6 までしか観測できなかった。そこで観測されて いない部分は炭素からの ${ }^{13} \mathrm{C}-{ }^{1} \mathrm{H}$ 相関、および NOE 実験等を利 用して帰属している。さらに彼らは、各糖残基の $\mathrm{H}-1$ を励起し た 1D NOESY を行い、GD1a の三次元構造解析も行っている。 この場合、まず、各糖のアノメリックシグナルを励起し、ミキ シングタイムを 0 から 1 秒まで可変させそれぞれ得られた $\mathrm{NOE}$ の強度をプロットしている。ガラクトースを例にとると、ガラ クトースの H-1 から、ガラクトースの 3 位への intra-NOE $\left(\mathrm{v}_{\mathrm{ij}}\right)$ を 基準に糖残基間の inter-NOE の強度 $\left(\mathrm{v}_{\mathrm{ik}}\right)$ の比を算出している。 また、比を取る際は、ガラクトースの 1 位シグナルから発生す るNOE 全てのシグナルの強度の増加が飽和していないグラフ上 の数值を用いている(図12)。そして、NOE の強度は距離の 6 乗 に反比例することからガラクトースの 1 位から還元末端側の糖 残基のプロトンとの距離 $\mathrm{r}_{\mathrm{ik}}$ をガラクトースの 1 位から 3 位の距 離 $r_{\mathrm{ij}}$ (内部標準 2.38 angstrom)を用いて算出している(10)。そして HSEA(Hard Sphere Exo Anomeric calculation) 法で糖鎖の三次元 構造をシミュレーションしている $(11)$ ささらにこの手法をもと に、インフルエンザウイルスのヘマグルチニン (12) やシアリ ダーゼ (13) に結合しているシアリルオリゴ糖の三次元構造解析 の研究を抢こなっている。Poppeらも同様に洗練された構造解 析法で、シアリルルイス Xとセレクチンとの結合時の糖鎖の三 次元構造解析を行っている (14)。

また、Danishefsky らは、糖鎖を数本ペプチド上に持つ分子 を合成し、NMR を用いて詳細な構造解析を行っている (15)。同 様に Halbeek (16) や Vliegenthart (17) らは糖鎖の 'H NMR を HMQC-TOCSY 法で完全解析している。特に、Halbeek らは異種 の糖鎖が混在するグライコフォームにおいてもそれぞれの糖鎖 の解析に成功している。この実験では、HMQCにより H-1 シグ ナルを抽出し、これに対してスピンロッキング時間を可変した TOCSY 法で各糖環内の ${ }^{1} \mathrm{H}$ へ相関させ、順番に環内プロトンの 帰属を行っている。これらの実験では、タンパクのカーボンシ グナルが糖のアノメリックカーボンの領域にほとんど観測され ないことから、1D ${ }^{1} \mathrm{H}$ NMR でアミノ酸のシグナルが糖シグナル に重なっていても帰属が可能である。また、Bock (18)、Imperiali (19)らも糖鎖ペプチドのアミドプロトンを含めた ${ }^{1} H$ NMR の完 全解析を行っている。

糖鎖の ${ }^{1} \mathrm{H}$ を完全解析することは、2D NOESY 実験を通し て糖鎖の三次元構造解析を行うために必須である。一般には、 2D Phase sensitive NOESY が有用であるが、そのクロスピーク にいくつかのシグナルが重なっている場合は、どこの ${ }^{1} \mathrm{H}$ 間に NOE が観測されるのか決定することが困難である。その場合 は、高分解能の 1D NOESY を測定して得られるシグナルの形、 J 值から決定することもできる。あるいは、HMQC-NOESYを 使って ${ }^{13} \mathrm{C}-{ }^{-1} \mathrm{H}$ 相関シグナルから、どの ${ }^{1} \mathrm{H}$ とどの ${ }^{1} \mathrm{H}$ の間に NOE が存在するか調べることも有効である。また、オリゴ糖が高分 子の場合は観測される NOEが負の領域で観測されるが、低分子 の場合は正となる。しかし、分子量が 700〜800 程度のオリゴ糖 
solve this problem, the 1D NOESY experiment is available to analyze where the protons show the NOE network, because the NOE signal can be assigned based on the signal shape and coupling pattern observed from the high resolution 1D NOESY spectrum. On the other hand, the HMQC-NOESY method is also effective to assign the NOE signal by use of correlation signal of proton and carbon signal. In the NOE experiments, NOE signals are observed as a negative sign when the large oligosaccharides are used in the experiment. On the other hand, small ones show the positive sign. However, the intensity of NOE for oligosaccharides with a molecular weight of around 700-800 sometimes shows as very small or mostly zero. This phenomenon is based on the value of $\tau_{c} \omega_{.0}=1$, where the $\omega_{0}$ and $\tau_{c}$ is the inverse of Larmor frequency and correlation time of the molecule, respectively, resulting in very low intensity of NOE signals (20). In order to observe the NOE signal on the above case, one of the conditions, such as field strength of the magnet or experimental temperature, should be varied in order to change the Larmor frequency (e.g. $500 \mathrm{MHz}$ to $400 \mathrm{MHz}$ ) or correlation time of the molecule. However, when the same instrument is used, ROESY experiment (Rotating-frame nuclear Over Hauser Effect SpectroscopY) would be applicable to such a molecule and the ROE signals are generated along the transverse axis compared to that of the NOESY phenomenon occurring along the Z-axis. Since the pulse sequences of ROESY and TOCSY are alike each other (Fig.13), the ROESY spectrum often contains several TOCSY signals. ROE signals can be easily distinguished in the mixture of ROE and TOCSY signals, because the sign of ROE signal is an opposite sign of the TOCSY. However, if both ROE and TOCSY signals occur toward the same proton signal, spin-locking time should be lengthened in order to decrease the TOCSY signal and increase the ROESY
はNOEが観測できない場合がある。これは、分子相関時間 $\tau_{\mathrm{c}}$ と 的をかけた值がほとんど 1 の場合の分子は NOE が観測しにく くなるためである $(20)$ 。この場合は、磁場 (例えば $500 \mathrm{MHz}$ ら $400 \mathrm{MHz})$ を代えて $\omega_{0}$ 值をずらすか、あるいは、測定温度を 変えて分子の運動性を変えることも有効な方法である。しか し、同じ装置しか使用できない場合は、NOESYではなくROESY を用いれば分子相関時間に関係なくNOE が観測できる。 NOESY は、回転座標系において Z 軸方向での磁化の強度の変 化が重要なのに対し、回転座標系で静磁場方向に直交する方向 にある横磁化の強度変調を NOE として観測するのが ROESYで ある。しかし、TOCSY と ROESY のパルスシークエンスは非常 に似ているため(図13)、得られる ROESY シグナルの中に TOCSY シグナルが混入してしまうことが多々ある。TOCSY シ グナルと ROESY シグナルは互いに反位相で観測されるので区 別はできるが、TOCSY シグナルと ROESY シグナルが1つの ${ }^{1} \mathrm{H}$ に同時に発生しうる場合は解析が困難になる。この場合は ROESY のスピンロッキング時間を徐々に長く(数 100 ミリ秒)し ていって、減少する TOCSY シグナル、増加する ROESY シグ ナルを帰属する必要がある(21)。

また、糖鎖の三次元構造を分析するために、グリコシル結 合周りの二面角を考察する方法も有用である。この場合、グリ コシル結合を介した ${ }^{13} \mathrm{C}-{ }^{-1} \mathrm{H}$ 間のロングレンジを利用する方法が ある。これは、非還元末端の糖の 1 位の炭素と還元末端側のグ リコシル化されている炭素に結合したプロトンとの遠隔カップ リング $\left(^{3} J_{H-l, C},{ }^{3} J_{C, H}\right)$ を測定し、Karplus の式より二面角を見積

2D TOCSY

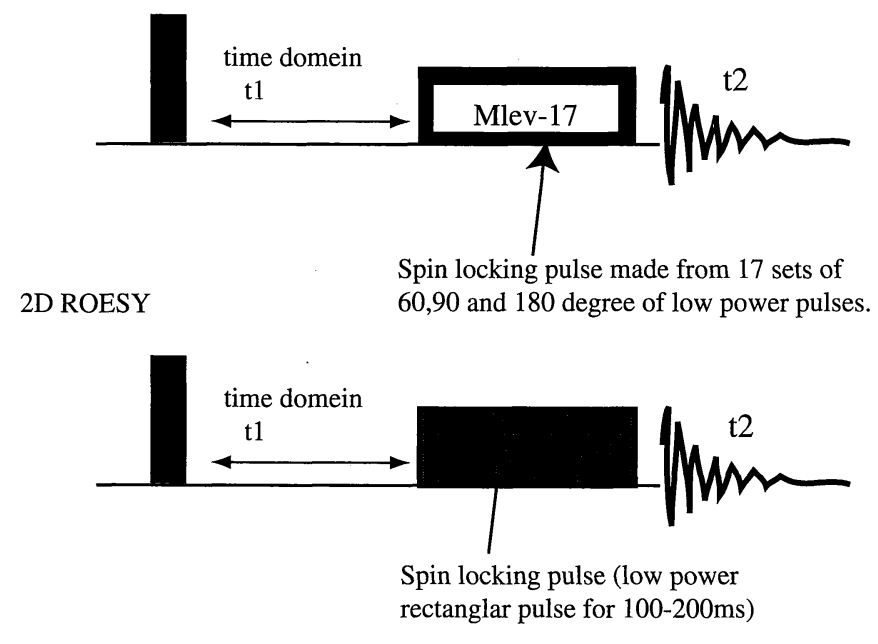

Fig. 13. Pulse sequences of 2D TOCSY and ROESY. 
signal (21).

In the conformational analysis, insight into the dihedral angle of a glycosyl bond is valuable. A convenient method is to estimate the dihedral angle around glycosyl linkage, using longrange coupling constants between the glycosyl bonds. This method requires measuring the coupling constants of $\underline{H}-\mathrm{C}-\mathrm{O}-\underline{\underline{C}}$ or $\underline{C}-\mathrm{O}-\mathrm{C}-\underline{H}$, and then estimating their dihedral angle by a Karplus equation (Fig.14) (21). However, since ${ }^{13} \mathrm{C}$ atom has a low natural abundance (ca $1.1 \%$ ), a high concentration of the sample would be essential in order to obtain a good result. To counteract this problem, stable isotope labeling at the anomeric carbon of the non reducing end sugar has been used. But a proton signal whose position is glycosylated by the labeled sugar should be found in the heavily crowded region ( $3-4 \mathrm{ppm})$. Therefore, an 1D-TOCSY experiment is a potential method, if the anomeric or the other proton signal of reducing end sugar is observed as a well-separated signal. In addition, 2D HMQC or HSQC spectra are also convenient methods to assign the proton signal correlating the carbon signal shifted to the low field by the glycosyl shift (21). However during this experiment, carbon decoupling power and the duration (e.g. GARP-decoupling) should be properly calibrated, because the decoupling pulse appears to distort the multiplicity of the long-range coupling constants due to heating by the decoupling.

Since stable isotope labeling is convenient to enhance the low sensitivity of carbon resonance, studies of the introduction of labeled sugar have also been examined. In this case, chemical or enzymatic methods are potential for labeling a mono sugar. The enzymatic method has more potential, because synthetic yield is relatively high compared to the chemical method. For the enzymes, glycosidase and glycosyltransferase are known to work well. In order to use glycosyltransferase, preparation of labeled sugar nucleotides which are the donor substrate, is essential. On the other hand, with glycosidase reaction (22), synthetic yield is not so good, because its reaction is reversible.
もる方法である(図14)(21)。しかし、この遠隔カップリングは ${ }^{13} \mathrm{C}-\mathrm{NMR}$ における感度が低いために (天然存在比 $1.1 \%$ ) 解析可 能な結果を得るには、高い濃度の糖鎖サンプルが必要となる。 この点の改良法として、非還元末端の糖残基の 1 位に安定同位 体を導入して同様な実験を行うと、効率よく遠隔カップリング を得ることができる。この場合、還元末端側の糖の ' $\mathrm{H}$ シグナル を観測し、 ${ }^{13} \mathrm{C}$ からの遠隔カップリングを測定することになる が、その 'H は最も多くのシグナルが重なっている 3〜 $4 \mathrm{ppm} に$ 観測されるため、通常の ${ }^{1} \mathrm{H} N \mathrm{NR}$ では解析が困難である。そこ で、還元末端の糖のアノメリックシグナルが低磁場に観測でき ていれば、そこを起点にして1D TOCSY を測定することで遠隔 カップリングを有するプロトンの抽出が可能になる。また、2D $\mathrm{HMQC}$ または HSQC を利用すれば、比較的各シグナルの分離が 可能になるため、目的とする還元末端の糖のグリコシル化され ている炭素上 ${ }^{1} \mathrm{H}$ を帰属できるとともに、遠隔カップリングを読 むことが可能である (21)。しかし、この場合は測定中の熱の発 生が遠隔カップリング值に影響を与えないようにするために、 ${ }^{13} C$ 側のデカップリングのパワーレベルや時間を適切に調整した 方がよい。

安定同位体を利用した標識糖は、 ${ }^{13} \mathrm{C}$ の感度を向上できるの で非常に有用で、その標識法の開発は過去いろいろと行われて いる。この場合、化学的、あるいは酵素的にラベルを導入する ことが有効である。また、この際、安定同位体で標識された糖 残基をオリゴ糖内に組み込むことが必要になるがこの場合は、 酵素を用いて導入する方が収率の面で有利である。酵素として は糖転移酵素、および糖加水分解酵素が挙げられる。糖転移酵 素の場合は標識糖を糖ヌクレオチド化する必要がある。また、 糖加水分解酵素 (22) を用いて標識糖を導入するには、酵素の逆

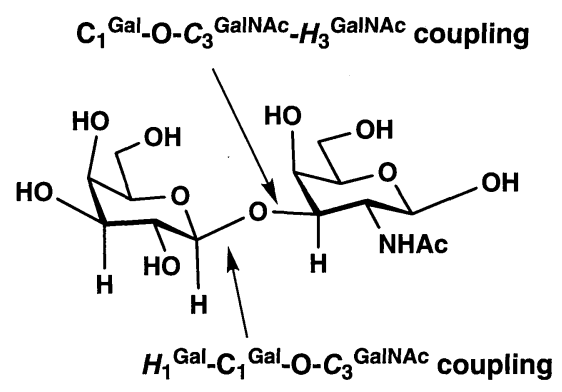

$$
{ }^{3} J_{C-H}=0.5-0.6 \cos \theta+5.7 \cos ^{2} \theta
$$

Fig. 14. Long range coupling constants for conformational analysis. 


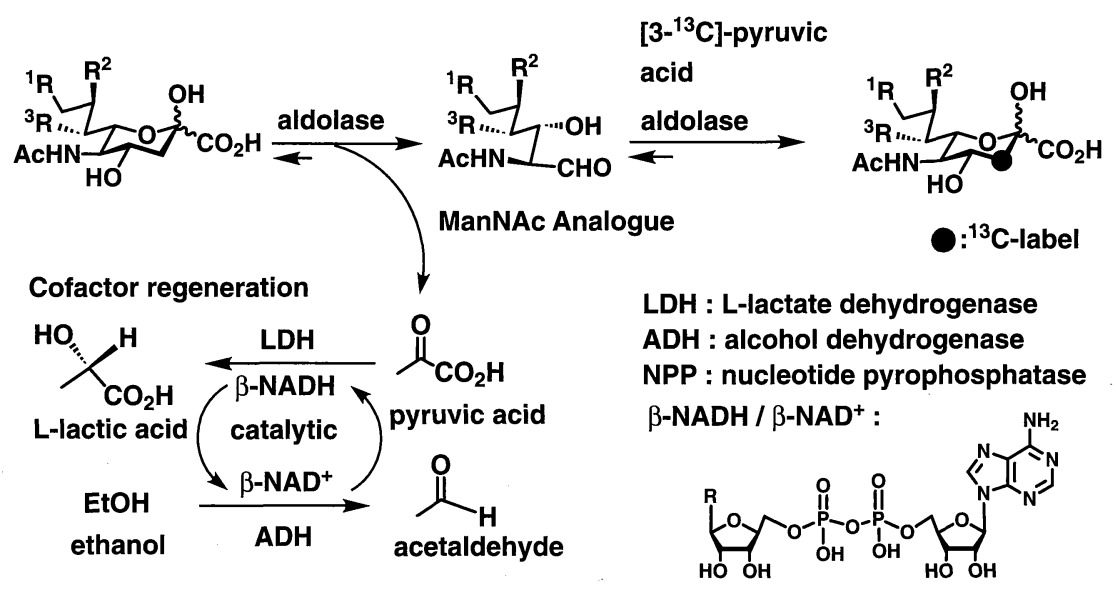

Fig. 15. Preparation method of $\left[3-{ }^{13} \mathrm{C}\right]$-labeled NeuNAc.

For the synthesis of stable isotope labeled sugar, stable isotope atoms should be inserted in the sugar skeleton by the reaction of $\mathrm{C}-\mathrm{C}$ bond formation such as Wittig reaction. In the case of sialic acid, Sato et al. demonstrated that a mixture of [3$\left.{ }^{13} \mathrm{C}\right]$-sialic acid and $\left[9-{ }^{13} \mathrm{C}\right]$-sialic acid synthesized shows the same NMR spectrum as $\left[3,9-{ }^{13} \mathrm{C}\right]$-sialic acid (23).

In order to synthesize the $\left[3-{ }^{13} \mathrm{C}\right]$-sialic acid analogues, we used reversible reaction of aldolase. Since synthetic methods of sialic acid analogues have been established, using these analogues for the synthesis of the $\left[3-{ }^{13} \mathrm{C}\right]$-sialic acid analogues would be very convenient. Therefore, sialic acid analogues were degraded to the $\mathrm{N}$-acetyl-D-mannosamine analogues by aldolase reaction and then $\left[3-{ }^{13} \mathrm{C}\right]$-pyruvic acid was condensed again to afford the $\left[3-{ }^{13} \mathrm{C}\right]$-sialic acid analogues. In this one pot reaction, direction in the equilibrium was controlled by use of a cofactor regeneration system decomposing the pyruvic acid derived from sialic acid analogues. This method affords several $\left[3-{ }^{13} \mathrm{C}\right]$-sialic acid analogues in $80-90 \%$ yield by a one pot reaction (Fig.15) (24). These $\left[3-{ }^{13} \mathrm{C}\right]$-sialic acid analogues were then converted into the cytidine- 5 '-monophospho- $\left[3-{ }^{13} \mathrm{C}\right]$-sialic acid (CMP-[3- $\left.{ }^{13} \mathrm{C}\right]$-sialic acid) .

In the case of galactose, uridine-5' -diphospho-[U- $\left.{ }^{13} \mathrm{C}\right]-$ galactose (UDP-[U- $\left.{ }^{-13} \mathrm{C}\right]$-galactose) have been enzymatically synthesized by Homans (25) and Goux et al. (26). These groups have demonstrated the transfer of the ${ }^{13} \mathrm{C}$-labeled galactose to the non reducing end of glycoprotein in order to have an insight into the dynamics of galactoside on the glycoprotein. The Shimada group has developed a useful stable isotope labeling method for oligosaccharides on the protein (27).

For other reports concerned with the dynamics of oligosaccharide on peptide or protein, the Imperiali (28) and Kahn (29) groups show that peptide conformation is affected by the GlcNAc residue at the reducing end of the asparagine linked oligosaccharide using extensive NMR analysis.

We also performed proton assignment and conformational
反応を利用して行うために、多少の収率低下は否めない。

安定同位体を糖に導入するには、糖骨格を構築する過程で Wittig 反応などを用いて化学的に導入する方法がある。シアル 酸の場合は、佐藤らにより、合成した $\left[3-{ }^{13} \mathrm{C}\right]-$ シアル酸と $\left[9-{ }^{13} \mathrm{C}\right]-$ シアル酸を $1: 1$ の比で混ぜても $\left[3,9-{ }^{13} \mathrm{C}\right]$-シアル酸と同様の NMR スペクトルが得られることが報告されている(23)。

また、我々は、 $\left[3-{ }^{13} \mathrm{C}\right]$-シアル酸を合成するために、アルド ラーゼの可逆反応を利用した(図15)。シアル酸の誘導体の化学合 成は多数報告例があるため、これら誘導体から $\left[3{ }^{-13} \mathrm{C}\right]-$ シアル酸 を合成できれば、非常に有用である。そこで、シアル酸誘導体 を一旦、アルドラーゼでマンノサミンとピルビン酸に分解さ せ、そして標識したピルビン酸と再縮合させて $\left[3-{ }^{13} \mathrm{C}\right]-$ シアル酸 誘導体を合成した。この方法では、シアル酸分解時に生成する ピルビン酸を分解することができる補酵素再生法を存在させる ことで可逆的なアルドラーゼの反応の方向を自由に制御しワン ポット反応により $\left[3-{ }^{13} \mathrm{C}\right]$-シアル酸誘導体を得ることができる。 この方法では、 $\left[3-{ }^{-13} \mathrm{C}\right]$-シアル酸誘導体を $80 \sim 90 \%$ の収率で得 ることができた(図15)(24)。そして得られたシアル酸誘導体は、 化学法により CMP-[3- $\left.{ }^{13} \mathrm{C}\right]-$ シアル酸へと変換した。

また、ガラクトースは、Homans (25)、および Goux (26)ら によって、 $\left[11^{13} \mathrm{C}\right]-$ ガラクトースを酵素的に UDP-[1- $\left.{ }^{13} \mathrm{C}\right]-$ ガラク トースへ変換した例が報告されている。また、彼らは、それぞ れ、糖タンパク質上の糖鎖末端へガラクトース転移酵素を用い て [1-13 C]-ガラクトースを組み込み、タンパク質上の糖鎖の末端 のガラクトースの挙動を ${ }^{13} \mathrm{C}$ NMR の緩和時間から考察してい る。また、Shimada らはタンパク質上の糖鎖の安定同位体標識 法を確立し、その構造解析をおこなっている(27)。

タンパク質やペプチド上の糖鎖の構造解析を行った他の例 としては、Imperiali (28) や Kahn (29) らのレポートがあげられ る。これらレポートでは、タンパク質のコンフォメーションに 影響を与えるのは還元末端側の N-アセチルグルコサミンである ことを、詳細なコンフォメーション、緩和時間の解析から考察 している。 
analysis of $\left[3-{ }^{13} \mathrm{C}\right]-\mathrm{NeuAc}-\alpha-2,3-\left[\mathrm{U}-{ }^{13} \mathrm{C}\right]-\mathrm{Gal}-\beta-1,4-\mathrm{GlcNAc}-$ sequence synthesized on the glycoprotein. For this synthesis, enzymatic transfer of $\left[3-{ }^{13} \mathrm{C}\right]$-sialic acid and $\left[\mathrm{U}-{ }^{13} \mathrm{C}\right]$-galactose was performed using CMP-[3- $\left.{ }^{13} \mathrm{C}\right]$-sialic acid, UDP-[U- $\left.{ }^{13} \mathrm{C}\right]$-galactose and corresponding glycosyltransferases (bovine $\beta-1,4-$ galactosyltrasferase and rat recombinant $\alpha 2,3$-sialyltransferase) (Scheme 1) (24). Assignment of galactoside was easily performed by $2 \mathrm{D} \mathrm{HMQC}$, because all carbons were labeled with a stable isotope atom, but ${ }^{1} \mathrm{H}-{ }^{-} \mathrm{H}$ coupling constants could not be measured due to multi ${ }^{1} \mathrm{H}-{ }^{13} \mathrm{C}-{ }^{13} \mathrm{C}$ coupling constants (Fig. 16A). On the other hand, since only one ${ }^{13} \mathrm{C}$ atom was inserted in the 3-position in NeuAc skeleton, it was impossible to assign all protons of NeuAc by HMQC. Therefore, HSQC-TOCSY method was used for assignment. But, in this case, TOCSY development also stopped at the 6-position due to the small coupling constant between $\mathrm{H}-5$ and $\mathrm{H}-6(<1 \mathrm{~Hz})$. In order to transfer the magnetization of H-6 to H-7 (Fig. 16B), we newly developed the HSQC-TOCSY-NOESY experiment based (Fig. 17) on the TOCSY-NOESY-TOCSY method(30). In order to excite an individual $\mathrm{H}-3$ of NeuAc, shaped pulses for both ${ }^{1} \mathrm{H}$ and ${ }^{13} \mathrm{C}$ were introduced to the standard HSQC-TOCSY pulse sequence, which was then replaced by the first $90^{\circ}$ pulse of NOESY pulse sequence. The reason for selecting the HSQC, is that coherence selection is simply made by single quantum. In addition, estimation of gradient ratio is simple compared to HMQC. The HSQC-TOCSY-NOESY experiment combined a conventional HSQC, TOCSY and NOESY pulse sequence. In order to simplify the phase cycling in the experiment, coherence selection from the beginning of the pulse sequence to position-a was em-
我々は、タンパク質上の糖鎖末端に合成した NeuAco2-3Gal$\beta-1,4-G l c N A c$ の三次元構造解析を NMR を用いて行った。この 場合、UDP-[U- $\left.{ }^{13} \mathrm{C}\right]-$ Galactose および CMP-[3- $\left.{ }^{-13} \mathrm{C}\right]$-sialic acid をそ れぞれガラクトースおよびシアル酸転移酵素を用いて糖タンパ ク質上の糖鎖末端に導入した(スキーム1)(24)。ガラクトース部 分の ${ }^{13} \mathrm{C}$ が全て標識してあるので、HMQCにより容易に帰属す ることができたが、 ${ }^{1} \mathrm{H}$ 間のカップリング定数は、 ${ }^{13} \mathrm{C}$ とのカッ プリングがあるためにその解析は困難であった(図16A)。一方、 シアル酸は 3 位 (C-3) にしか安定同位体が標識されていないの で HMQC 法で全ての ${ }^{1} \mathrm{H}$ を帰属することは不可能である。そこ で、HMQC-TOCSYを利用した。しかし、この場合もシアル酸 の H-6 と H-7 の間の $\mathrm{J}$ 值が小さいために、TOCSY 展開は 6 位 で停止する。そこで TOCSY-NOESY-TOCSY 法 (30)を改良し HSQC-TOCSY-NOESY 法を確立して、C-3 の安定同位体の磁化 をH-7にNOESYを介して伝えた(図16B)。この HSQC-TOCSYNOESY 法のパルスプログラムは、以下のようなコンセプトで作 成した(図17)。標準のHSQC-TOCSY 法の最初の部分にシェープ ドパルスを導入し、シアル酸の一方の ${ }^{1} \mathrm{H}$ のみを励起できるよう にし、そして selective-HSQC-TOCSY のパートを NOESY の最 初の 90 度パルスのところに代入した。HSQC 法を選んだ理由 は、磁化の励起が一量子遷移のみで容易に考えられることと、 必要のない磁化を消去するためのグラジュエントパルスの強度 比の計算が容易であるからである。この HSQC-TOCSY-NOESY は標準的な HSQC、TOCSY およびNOESY 法を組み合わせたも のであるが、いくつかの工夫がなされている。第一に、グラ ジェントパルス G1 と G3 によって、パルスシーケンスのはじ めから a 地点までコヒーレンスセレクションを行なっている。
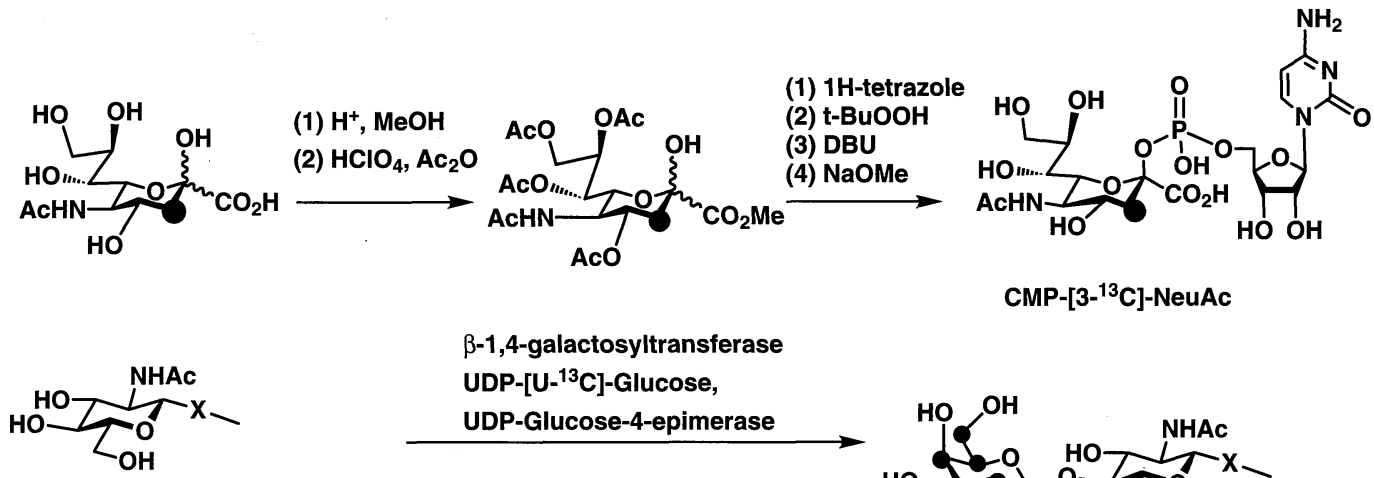

$\beta-1,4-$ galactosyltransferase UDP-[U- $\left.{ }^{13} \mathrm{C}\right]$-Glucose UDP-Glucose-4-epimerase

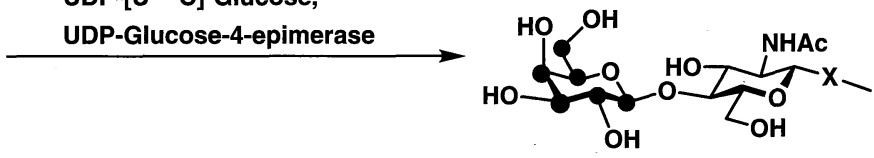

Ovalbumin (MW : 45,000)

(1) $\alpha-2,3-(\mathrm{N})$-sialyltransferase CMP-[3- $\left.{ }^{13} \mathrm{C}\right]-\mathrm{NeuAC}$ (2) $\beta$-galactosidase

Sialylation: ca $60 \%$

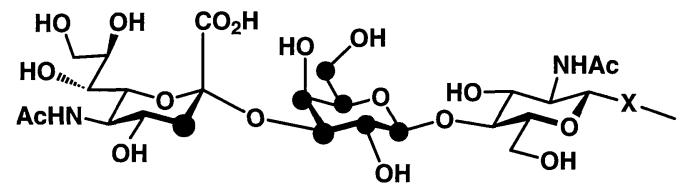

Scheme 1. Synthesis of stable isotope labeled glycoprotein. 


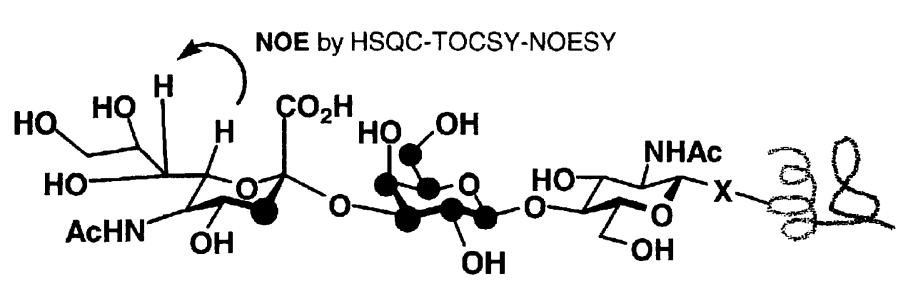

A) HMQC spectrum

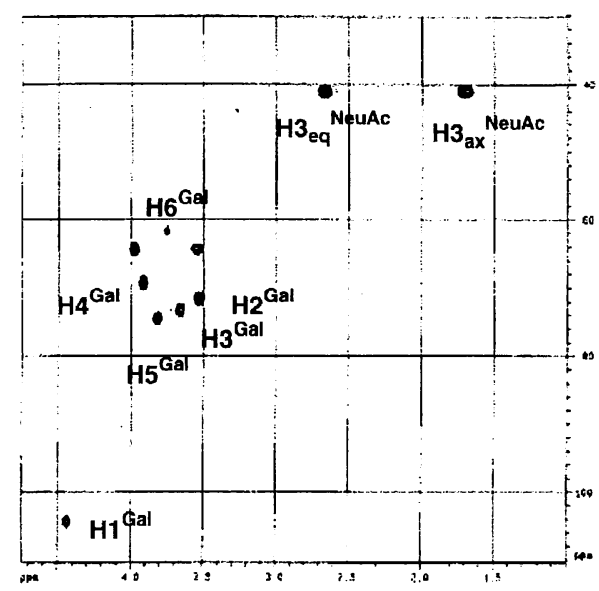

HSQC-TOCSY-NOESY spectrum

B)

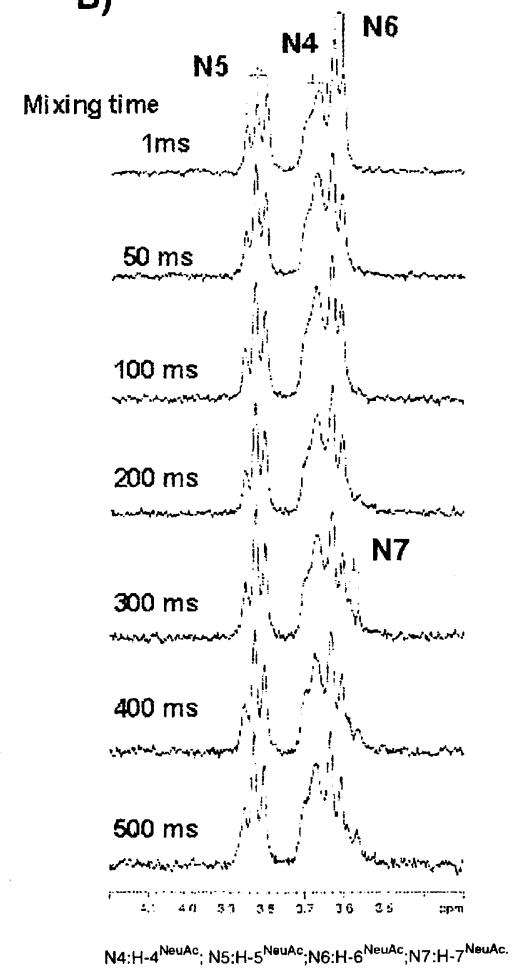

Fig. 16. HMQC and HSQC-TOCSY-NOESY spectra of sialoside on protein.
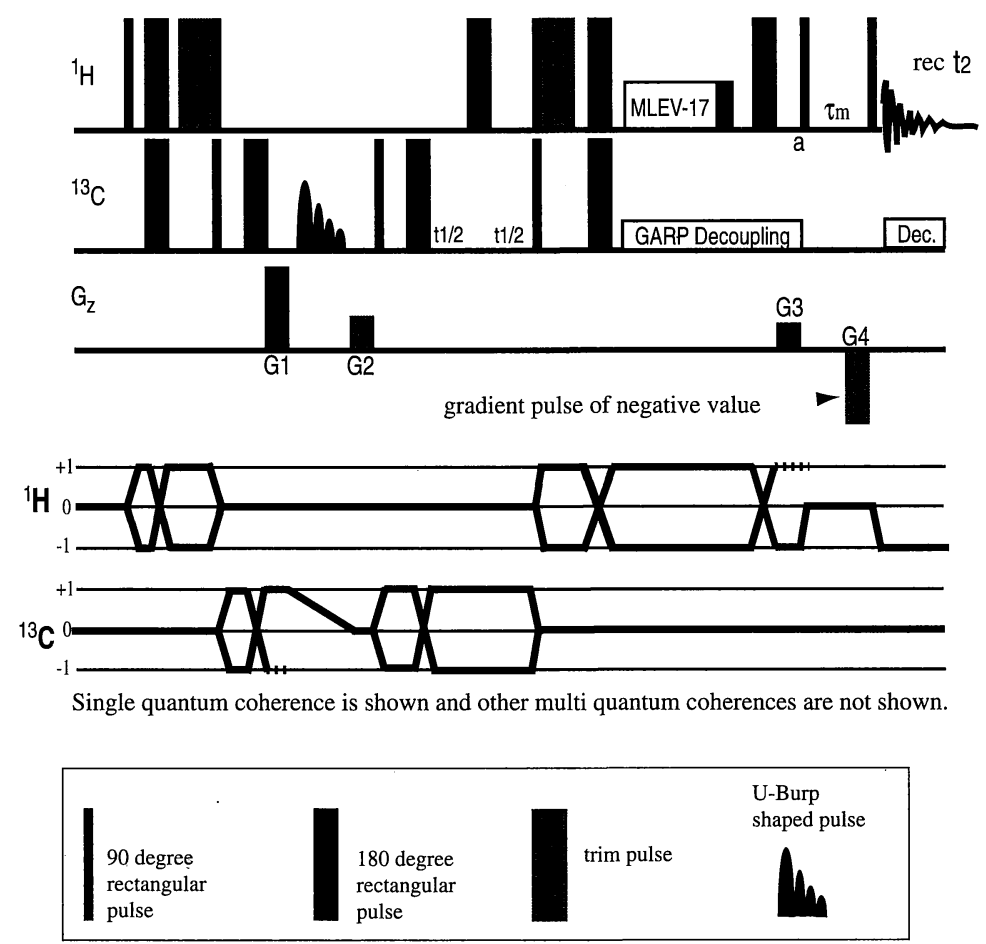

Fig. 17. Pulse sequence and coherence order. 
ployed by the pulsed-filled gradient (pulses) (G1 and G3). Therefore, phase-cycling is not needed for the beginning to position$a$ in the experiment and is achieved with 1 scan in principle, as below:

\author{
$\Sigma \mathrm{GiPi}=0$ \\ $\gamma$ : gyro magnetic ratio $\left({ }^{1} \mathrm{H}\right.$ or $\left.{ }^{13} \mathrm{C}\right)$ \\ Gi: Gradient Strength \\ Pi: Coherence Order \\ If $\mathrm{G} 1: \mathrm{G} 3=4: 1$ \\ at G1, $1 \mathrm{H}: 4 \times 0=0$ and $13 \mathrm{C}: 1 / 4 \times 4 \times 1=1$ \\ (1/4: Gamma ration of $13 \mathrm{C}$ and $1 \mathrm{H})$ \\ at $\mathrm{G} 3,{ }^{1} \mathrm{H}:-1 \times 1=-1$ and ${ }^{13} \mathrm{C}: 1 / 4 \times 1 \times 0=0$ \\ $0+1+(-1)+0=0$
}

Therefore, only bold lines in the pulse sequence are achieved the coherence selection (coherence order of -1 is expressed in Fig. 17). And a gradient pulse was introduced after NOE-mixing time, in order to eliminate the artifact such as a COSY peak. Hence, 2-scanning was available for the phase cycling from point-a to the end of the pulse sequence. Finally, 2scanning can be accumulated in this experiment in principle. However, 2-scanning normally does not give high sensitivity. The sign of the phase of pulse and receiver were changed and the receiver phase was practically set to $\mathrm{x},-\mathrm{x}, \mathrm{x},-\mathrm{x},-\mathrm{x}, \mathrm{x},-\mathrm{x}, \mathrm{x}$. Furthermore, in order to selectively extract the magnetization of the 3-positon in NeuAc residue (C-3), a selective 90-degree pulse (E-BURP) for ${ }^{13} \mathrm{C}$ was employed after INEPT sequence. All magnetization except for $\mathrm{C}-3$ was spoiled and then only the magnetization of C-3 was back to the $\mathrm{y}$-axis by the next 90 degree pulse on ${ }^{13} \mathrm{C}$.

1D HSQC-TOCSY-NOESY-TOCSY experiment is easily extended by connecting a selective-TOCSY sequence to the HSQC-TOCSY-NOESY. Because the TOCSY sequence can be accumulated with 1-scanning, the same phase cycling of the HSQC-TOCSY-NOESY experiment was used for the 1D HSQCTOCSY-NOESY-TOCSY experiment. This method enabled us to performe full assignment from $\mathrm{H}-3$ to H-9 even with only one ${ }^{13} \mathrm{C}$ atom at the 3-position of NeuAc (24).

Hence, we also performed selective HMQC and selective HMQC-NOESY experiments to analyze the conformational properties of $\left[3-{ }^{13} \mathrm{C}\right]-\mathrm{NeuAc}-\alpha-2,3-\left[\mathrm{U}-{ }^{13} \mathrm{C}\right]-\mathrm{Gal}-\beta-1,4-\mathrm{GlcNAc}$ sequence.

For this analysis, we measured NOE by both $1 \mathrm{D}$ and 2D HMQC-NOESY techniques. In the 2D HMQC-NOESY spectrum, we observed NOEs to H-4 $4^{\mathrm{NeuAc}}, \mathrm{H}-5^{\mathrm{NeuAc}}$, and H-3 $3^{\mathrm{Gal}}$ from either $\mathrm{H}-3 \mathrm{ax}^{\mathrm{NeuAc}}$ or $\mathrm{H}-3 \mathrm{eq}^{\mathrm{NeuAc}}$. We could not determine whether the NOE was derived from $\mathrm{H}-3 \mathrm{ax}^{\mathrm{NeuAc}}$ or $\mathrm{H}-3 \mathrm{eq}^{\mathrm{NeuAc}}$, because the 2D HMQC-NOESY spectrum shows NOE's to H-4 $4^{\mathrm{NeuAc}}, \mathrm{H}-$ $5^{\mathrm{NeuAc}}$, and $\mathrm{H}-3^{\mathrm{Gal}}$ at the same chemical shifts as the $\mathrm{C}-3^{\mathrm{NeuAc}}$ in the F1-dimension (Fig. $18 \mathrm{~A}$ ). Therefore, we modified the pulse sequence of 1D HMQC-NOESY in order to determine whether the NOE resulted from $\mathrm{H}-3 \mathrm{ax}$ or $\mathrm{H}-3 \mathrm{eq}$ in NeuAc. We changed
これによって 1 回積算により必要な情報を得ることができ、位 相回しは必要がない。NMR シグナルの観測条件にはグラジェン トパルス、コヒーレンスオーダーについて前述の $\Sigma \mathrm{GiPi}=0$ とい う関係があり、グラジェントパルスの強度とそのときのコヒー レンスオーダーとの積の総和が 0 のとき NMR シグナルとして 観測される。G1:G3=4:1のとき、G1 において 'H は $4 \times 0=0$ 、 ${ }^{13} \mathrm{C}$ は $1 / 4 \times 4 \times 1=1\left(1 / 4\right.$ は ${ }^{13} \mathrm{C}$ と ${ }^{1} \mathrm{H}$ のガンマ比)、G3において ${ }^{1} \mathrm{H}$ は $-1 \times 1=-1 、{ }^{13} \mathrm{C}$ は $1 / 4 \times 1 \times 0=0$ となる。したがって太線で 示したパスのみが $0+1+(-1)+0=0$ となり、コヒーレンスセレ クションが達成される(図17、コヒーレンスオーダーが-1のも ののみ表示した)。また、NOE 混合時間の最後にグラジェントパ ルス G4 を出している。これにより、XY 平面に残存する COSY 由来のアーティファクトを除くことができ、a 地点以降の NOESY 部分の位相回しは 2 回で実験することができる。した がって今回の HSQC-TOCSY-NOESY は基本的には位相回し 2 回 で行なうことができる。実際には 2 回積算では感度が悪いため に、積算回数を増やした。そこでこの場合はパルスおよびレ シーバーの位相を反転させて $\mathrm{x} 、-\mathrm{x} 、 \mathrm{x} 、-\mathrm{x} 、-\mathrm{x} 、 \mathrm{x} 、-\mathrm{x} 、 \mathrm{x}$ で行 なった。また、2つめの工夫として、INEPTによって ${ }^{1} \mathrm{H}$ から ${ }^{13} \mathrm{C}$ に磁化が移動したのち、シアル酸残基の C-3 に選択的な 90 度 パルスを出している。これによって C-3 の磁化のみが Z 軸方向 に向き、その他すべての ${ }^{13} \mathrm{C}$ は $\mathrm{XY}$ 平面上に残すことができる。 この直後のグラジェントパルス $\mathrm{G} 3$ は $\mathrm{XY}$ 平面上に存在する磁 化をスポイルし、C-3 のみが影響を受けないことになる。つい で 90 度パルスにより、C-3 の磁化のみを Y 軸上に戻している。

1D HSQC-TOCSY-NOESY-TOCSY は HSQC-TOCSY-NOESY (30) の拡張版であり、NOESYのうしろに選択励起パルスを用い た TOCSYを組み込んだものである。この TOCSY は位相回し の必要ないシーケンスなのでHSQC-TOCSY-NOESY と同じ位相 回しを用いた。この結果、このように安定同位体 1 つでシアル 酸の全ての ${ }^{1} \mathrm{H}$ の観測に成功した $(24) 。$

また、NeuAc $\alpha 2-3-G a l-\beta-1-4-G l c N A c$ の三次元構造を解析す るために、selective-HMQC と selective-HMQC-NOESY 法を作成 した。分析法としては、1D NOESY と 2D NOESYを用いたが、 シアル酸のアキシアルまたはエカトリアルの H-3 からシアル酸 の H-4 と H-5 およびガラクトースの H-3 N NOE が発生してい た。しかし、シアル酸の H-3 から HMQC-NOESY 法を行った 際、アキシアルまたはエカトリアルのどちらの H-3 から NOE が 発生しているか 2D HMQC-NOESY 法では判断できない (図 18A)。そこで、2D HMQC-NOESY 法を改良して、シアル酸の H3 の一方のみを選択的に励起できるようした。まず、2D HMQC の ${ }^{~} \mathrm{H}$ およよ゙ ${ }^{13} \mathrm{C}$ 周波数チャンネルにおいて 90 度パルスをガウ 

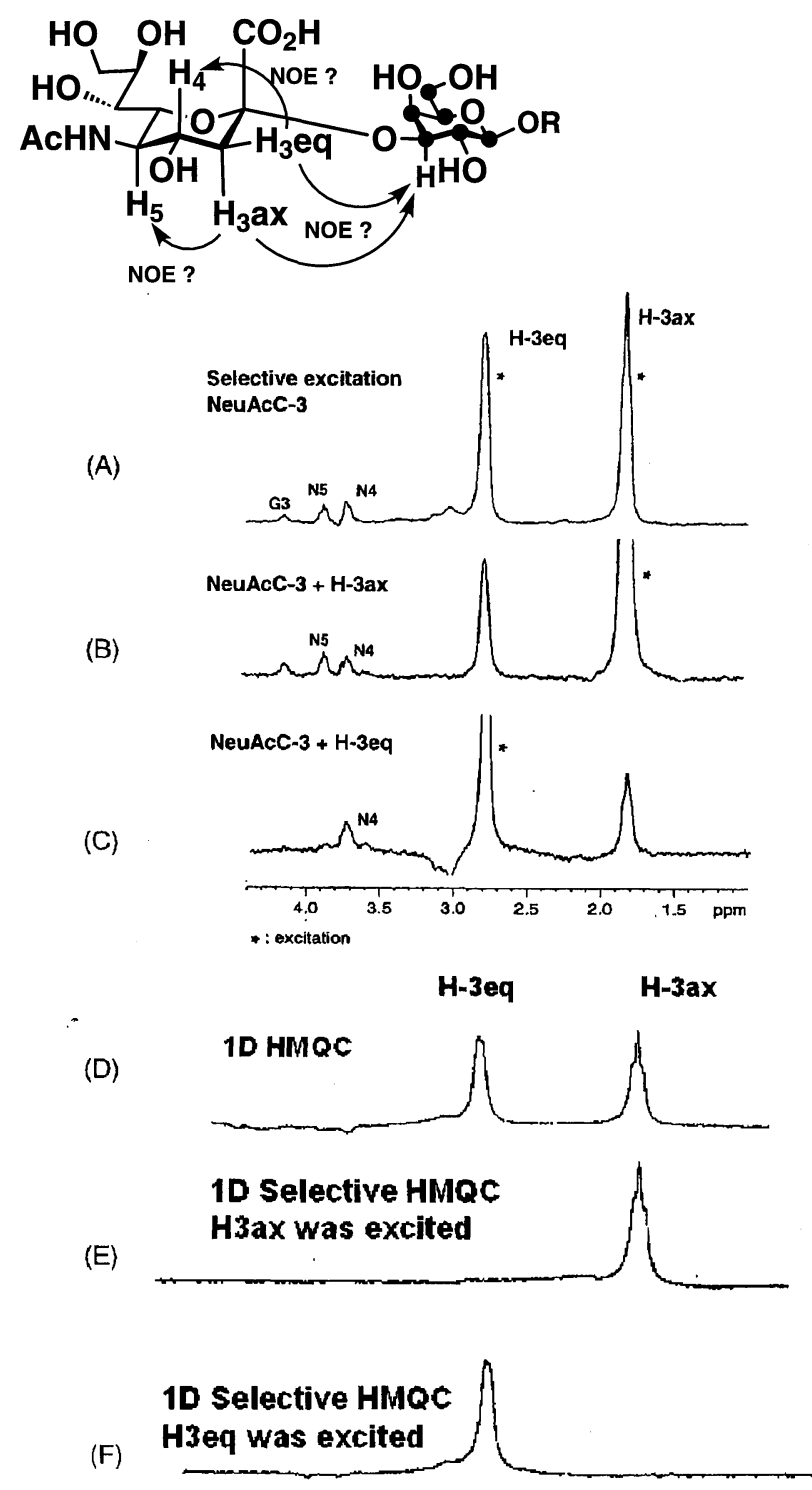

Fig. 18. HMQC-NOESY (B) (C) and Selective HMQC (E), (F). G3: H-3 $3^{\text {Gal }}$ N4: H-4 ${ }^{\text {NeuAc }}$; N5: H-5 $5^{\text {NeuAc }}$

the two rectangular pulses $\left(90^{\circ}\right)$ for both proton and carbon to Gaussian and half-Gaussian shaped selective pulses, respectively, in the standard HMQC pulse sequence. The pulse sequence is summarized in Fig.19. In this experiment, the Gaussian shaped pulse adjusted to the resonance of the desired one of $\mathrm{H}-3$ axial or equatorial proton, and half-Gaussian pulse adjusted to the resonance of only C-3. The reasons for substitution of a- and c90 degree pulses by Gaussian and half-Gaussian pulses, respectively, are as follows. Since the first three pulses $(90,180$, and 90-degree) for protons and first 180-degree pulse for carbons are a typical pulse set known as a BIRD pulse, only a-90 degree pulse can be substituted with the shaped pulse for excitation of the H-3 axial. For the carbon pulse, substitution of c-90 degree pulses by half-Gaussian was experimentally successful. With the phase cycling of the shaped pulse, although the calibration
シアンおよびハーフガウシアンシェープドパルスに変えた。そ のパルスシークエンスは図19に示した。この実験では、ガウシ アンパルスは、シアル酸の H-3 のアキシアルまたは、エカトリ アル位のどちらかに合わせ、ハーフガウシアンパルスは、シア ル酸のC-3 のケミカルシフトに相当する周波数に合わせた。パ ルス a と c をガウシアン、ハーフガウシアンに代えた理由は以 下の通りである。 ${ }^{1} \mathrm{H}$ に対する最初の 90、180、90 度パルスと 最初の ${ }^{13} \mathrm{C} へ の 90$ 度パルスは BIRD パルスというセットになっ ているため、a の 90 度パルスのみ $\mathrm{H}-3$ を選択的に励起する シェープドパルスに置換可能であった。 ${ }^{13} \mathrm{C}$ 側のシェープドパル スの置換については、CとDのパルスがシェープドパルスによ り置換可能であった。しかし、実験的に $\mathrm{c}$ パルスをハーフガウ シアンで置換したことで成功した。位相回しは、'H励起に使用 するガウシアンパルスについては位相補正をしたが、その他は オリジナルのものをそのまま利用した。また、この際、 ${ }^{13} \mathrm{C}$ 側の 
A) 2D HMQC

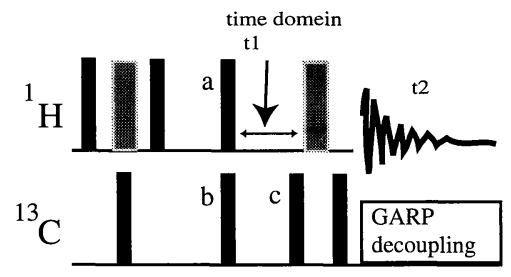

B) 1 D selective HMQC
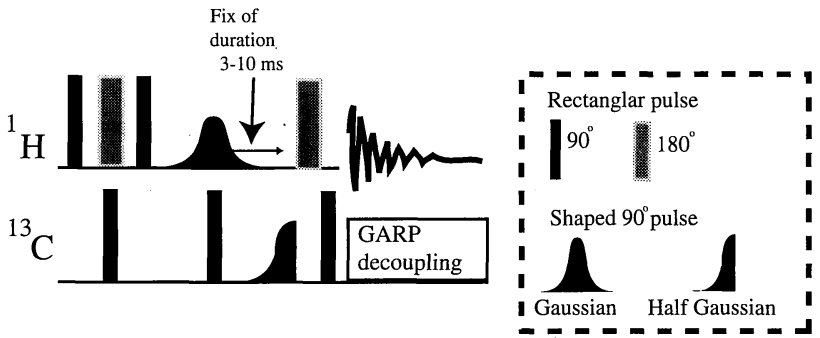

C) 1D selective HMQC-NOESY

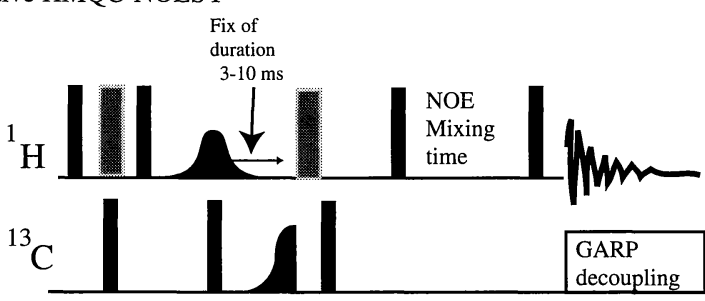

Fig. 19. Preparation of $1 D$ selective experiment from conventional $2 D$ experiments.

of the phase was applied to the gaussian pulse for proton excitation, standard phase cycle of HMQC was used. On the other hand, the calibration of the phase difference between hard and shaped pulses on ${ }^{13} \mathrm{C}$-channel was not essential. These simple modifications enabled us to make the desired pulse sequence and selective excitation for one of $\mathrm{H}-3$ axial and equatorial individually on the glycoprotein (Fig $18 \mathrm{E}, \mathrm{F}$ ). According to this concept, we also applied this HMQC pulse sequence into standard HMQC-NOESY. This pulse sequence enabled us to determine where the NOE was derived from $\mathrm{H}-3$ axial or equatorial protons (Fig 18B, C and Fig 19C) (24).

As described, a simple rule mastered enabled us to make tailor made pulse sequences. In addition, we also examined selective-TOCSY-DQFCOSY experiments (31). If several ${ }^{1} \mathrm{H}$ signals overlap in the 1D TOCSY spectrum, unambiguous assignment would be a hindrance. In order to make a pulse sequence, the first 90-degree pulse in DQFCOSY sequence (1) was substituted by a pulse set of 1D selective-TOCSY as shown in Figure 20C. Magnetization of a desired mono sugar extracted by $1 D$ TOCSY was then applied to DQFCOSY toward the second dimension for the strict assignment of an individual sugar component in oligosaccharides with a pulsed field gradient. The proton signals for a selected sugar in an oligosaccharide are ob-
励起に使うシェープドパルスには、位相補正をしていない。そ して、この簡単なプログラム補正により、タンパク質に結合し たシアル酸の 3 位の一方のプロトンを任意に励起できるように なった(図18E、F)。そして、このコンセプトを利用し、その磁化 がそのままNOESY に利用できるように、HMQC-NOESY 法の パルスシーケンスの最初の HMQC 部分に selective-HMQC のパ ルス配列を導入した(図 18B、C および図19C)(24)。

このように回転座標系での各パルス配列の最後の磁化がど のような状態であるかを理解できれば、任意のパルス配列と組 み合わせ、必要なパルスプログラムをオリジナルに作成するこ とができる。

また、このアイデアを応用して selective-TOCSY-DQFCOSY 法も検討した(31)。1D TOCSY 法で得られるシグナル中のいく つかのシグナルが重なり合っている場合は、その帰属が経験的 なものになる可能性がある。そこで、前述の方法と同様に、 DQFCOSY の最初の 90 度パルスを 1D-TOCSY に換えた(図 20C)。そして、オリゴ糖の中の任意の単糖の FID を観測し始め たときの状態に DQFCOSY のパルス配列 (1) も組み込めば(図 20C)、選んだ単糖の 2D DQFCOSY が得られることになる。そ してこれにグラジュエントパルスを組み达むことで厳密な帰属 ができるような良好なスペクトルを得ることができる。最初の 


\section{A 1D TOCSY}

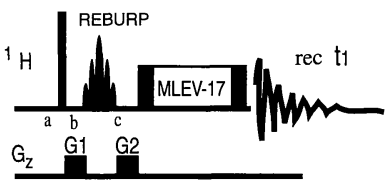

B 2D DQF COSY
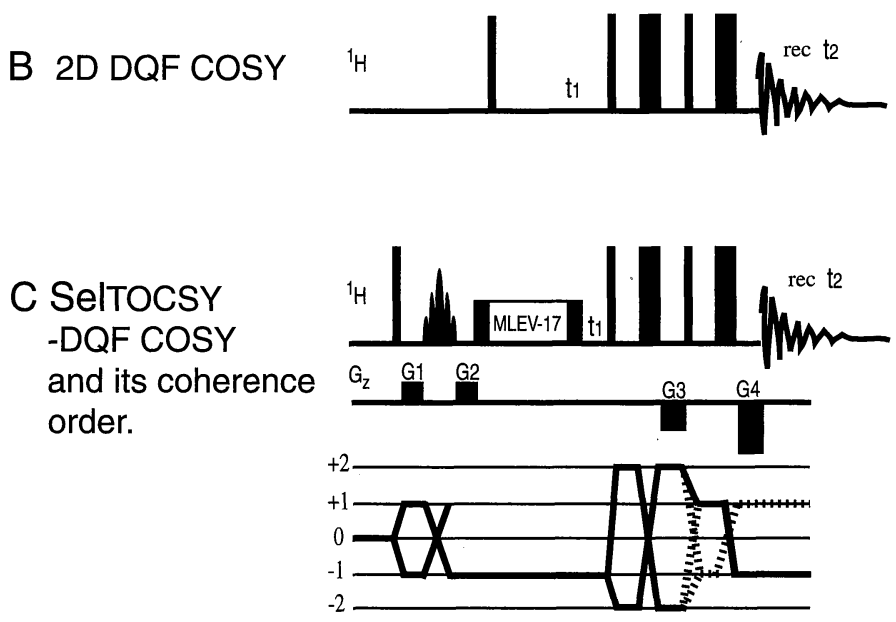

Only double quantum coherence is shown

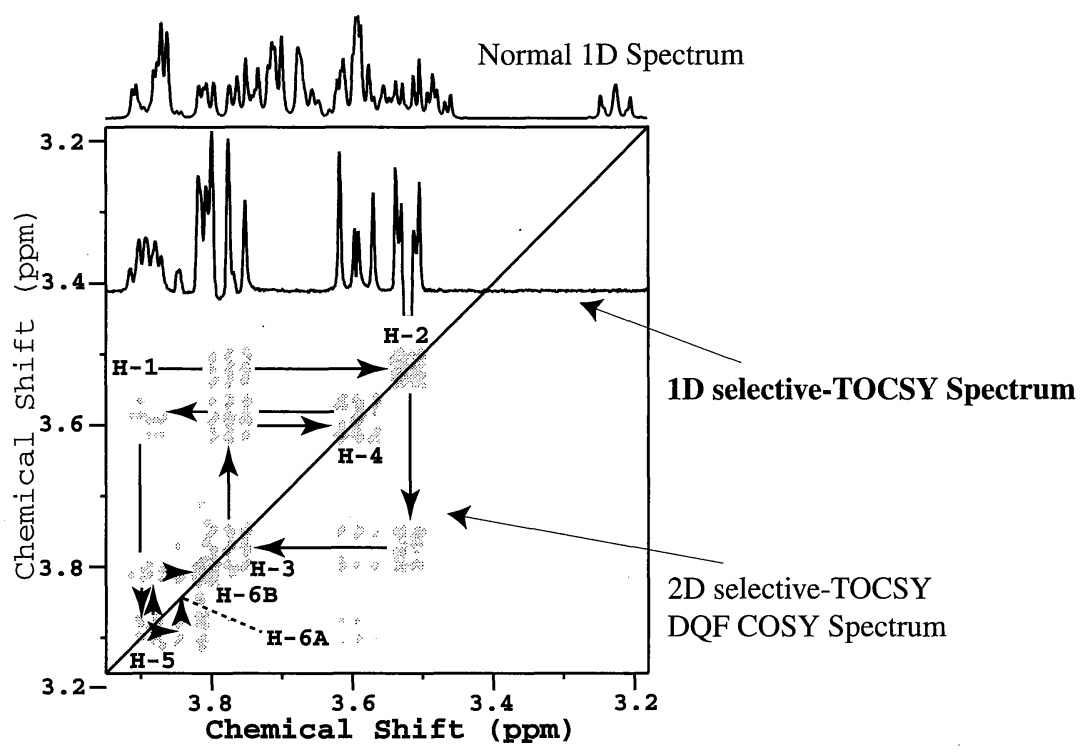

Fig. 20. Pulse sequences of 2D TOCSY, DQF COSY and selective TOCSY-DQFCOSY.

served as diagonal peaks in the 2D spectrum by use of the first selective TOCSY period, and the correlation signals between Jcoupled neighboring protons are clearly observed as the cross peak, including even the signals observed close to the diagonal (Fig.20).

\section{E. Conclusion}

As described here, the structural analysis of oligosaccharide is difficult due to severely overlapping proton signals. Recently, several NMR experiments that have been developed,
1D TOCSY で抽出された単糖の H-1 から H-6 は、 selectiveTOCSY-DQFCOSY の対角ピークとして、またカップリングして いる隣りの'Hとの相関は、クロスピークとして観測できる。ま た、この際、そのクロスピークが対角ピークの近傍に位置して いても、はっきりと観測することができる(図20)。

\section{E. 総 括}

以上、述べたように複雑な構造の糖鎖は多数のプロトンを 有しているためにその解析は困難な場合が多い。しかし、近 年、様々なパルスプログラムを用いて糖鎖の全ての ${ }^{1} \mathrm{H}$ を帰属で 
enabled us to assign proton and carbon signals in oligosaccharides (32-34). But if organic and biochemists can modify pulse sequences, tailor made NMR experiments would be examined toward their oligosaccharide samples. In the future, the focus would be on the roles of large oligosaccharides, so dealing with NMR instruments in the structural analysis of oligosaccharides would afford useful structural information. We hope this minireview helps towards such research.
きるようになっている(32-34)。しかし、本総説のように研究者 自身で必要なパルス配列を作製することができれば、どのよう な複雑な構造の糖鎖でも、その解析は可能になる。今後大型の 糖鎖の機能に注目が集まることが考えられるが、そのようなと きに研究者が自在にNMR 測定法をつくることができれば、よ り多くの情報を得ることが可能になる。本総説がそのような研 究の一助になれば幸いである。

\section{References}

1. Piantini, U., Sorensen, O.W., and Ernst, R.R. (1982) J. Am. Chem. Soc. 104, 6800-6801

2. A. Bax \& D.G. Davis, J. Magn. Reson. (1985) 65, 355-360

3. Kessler, H., Oschkinat, H., and Griesinger, C. (1986) Journal of Magnetic Resonance 70, 106-133

4. Kessler, H., Mronga, S., and Gemmecker, G. (1991) Magn. Reson. Chem. 29, 527-557

5. Parella, T. (1998) Magn. Reson. Chem. 36, 467-495

6. J. Stonehouse, P. Adell, J. Keeler \& A.J. Shaka, (1994) J. Am. Chem. Soc 116, 6037

7. Vliegenthart, J.F.G., Dorland, L., and van Halbeek, H. (1983) Advances in Carbohydrate Chemistry and Biochemistry 41, 209-374

8. Vuister, G.W., de Waard, P., Boelens, R., Vliegenthart, J.F.G., and Kaptein, R. (1989) J. Am. Chem. Soc. 111, 772-774

9. Sabesan, S., Duus, J.O., Fukunaga, T., Bock, K., and Ludvigsen, S. (1991) J. Am. Chem. Soc. 113, 3236-3246

10. Poppe, L., Von der Lieth, C.W., and Dabrowski, J. (1990) J. Am. Chem. Soc. 112, 7762-7771

11. Sabesan, S., Bock, K., and Paulson, J. C. (1991) Carbohydrate Research 218, 24-54

12. Sabesan, S., Duus, J.O., Neira, S., Domaille, P., Kelm, S., Paulson, J.C., and Bock, K., (1992) J. Am. Chem. Soc. 114, 8363-8375

13. Sabesan, S., Neira, S., Davidson, F., Duus, J.O., and Bock, K. (1994) J. Am. Chem. Soc. 116, 1616-1634

14. Poppe, L., Brown, G.S., Philo, J.S., Nikrad, P.V., and Shah, B.H. (1997) J. Am. Chem. Soc. 119, 1727-1736

15. Coltart, D. M., Royyuru, A. K., Williams, L. J., Glunz, P. W., Sa,es, D., Kuduk, S. D., Schwarz, J. B., Chen, X.-T., Danishefsky, S. J., and Live, D. H. (2002) J. Am. Chem. Soc. 124, 9833-9844

16. Lu, J., and van Halbeek, H. (1996) Carbohydrate Research 296, 1-21

17. Hokke, C.H., Bergwerff, A. A., Van Dedem G. W. K., Kamerling, J. P., and Vliegenthart, J. F. G. (1994) Eur. J. Biochem. 228, 981-1008

18. Meinjohanns, E., Meldal, M., Paulsen, H., Dwek, R.A., and Bock, K. (1998) J. Chem. Soc., Perkin Trans. 1, 549-560

19. O'Connor, S.E., Pohlmann, J., Imperiali, B., Saskiawan, I., and Yamamoto, K. (2001) J. Am. Chem. Soc. 123, 6189-6188

20.Bax, A., Sklenar, V., Summers, M. F., (1986) J. Magn.Reson. 70, 327

21. Ichikawa, Y., Lin, Y.C., Dumas, D. P., Shen, G. J., Garcia-Junceda, E., Williams, M.A., Bayer, R., Ketcham, C., Walker, L. E., Paulson, J. C., and Wong , C. H. (1992) J. Am. Chem. Soc. 114, 9283-9298

22. Probert, M. A., Milton, M.. J., Harris, R., Schenkman, S., Brown, J. M., Homans, S.W., Field, R. A., (1997)Tetrahedron Letters, 38, 58615864

23. Sato, K., Akai, S., Hiroshima, T., Aoki, H., Sakuma, M., Suzuki, K., (2003) Tetrahedron Letters, 44, 3513-3516

24. Miyazaki, T., Sato, H., Sakakibara, T., Kajihara, Y., (2000) J. Am. Chem. Soc., 122, 5678-5694

25. Gilhespy-Muskett, A. M., Partridge, J., Jefferis, R., and Homans, S. W. (1994) Glycobiology 4, 485-489

26. Goux, W. J., Perry, C., and James, T. L. (1982) J. Biol. Chem. 257, 1829-1835

27. Yamaguchi, Y., Takizawa, T., Kato, K., Arata, ., Shimada, I., (2000) J. Biomol. NMR, 18, 357-360

28. O'Connor, S. E., and Imperiali, B. (1998) Chemistry \& Biology 5, 427-437

29. Liang, R., Andreotti, A. H., and Kahne, D. (1995) J. Am. Chem. Soc. 117, 10395-10396

30. Uhrin, D., Brisson, J. -R., Kogan, G., Jennings, H. (1994) J. Magn. Res., 104, 289-293

31. Sato, H., Kajihara, Y.(2003) J. Carbohydr. Chem. 22, 339-345

32. Homans, S. W. (1993) Glycobiology 3, 551-555

33. Kessler, H., Gehrke, M., and Griesinger, C. (1988) Angew. Chem. Int. Ed. Engl. 27, 490-536

34. Duus, J. O., Gotfredsen, C. H., and Bock, K. (2000) Chem. Rev. 100, 4589-4614

Received on July 12, 2003, accepted on July 26, 2003 


\section{Appendix-1}

Trends in Glycoscience and Glycotechnology Vol.15 No.84 (July 2003) pp.197-220

\section{Double quantum filtered}

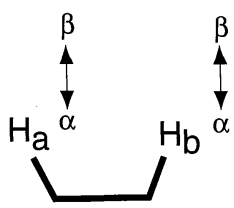

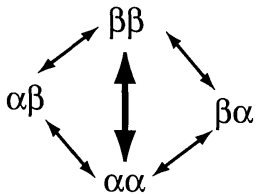

When both $\mathrm{H}_{a}$ and $\mathrm{H}_{b}$ couple with each other double quantum means transient from $\alpha \alpha$ to $\beta \beta$ state. Double quantum filtered system detects only double quantum state.

2 つのプロトンがカップリングしているとき、 $\alpha \alpha$ から $\beta \beta$ 状態になることを 2 量子遷移という。 2 量子フィルターは、この状態の磁化のみ観測する。

$\alpha \alpha$ to $\alpha \beta$ and $\beta \alpha$ : single quantum.

$\alpha \alpha$ to $\beta \beta$ : double quantum.

\section{Spin locking pulse}
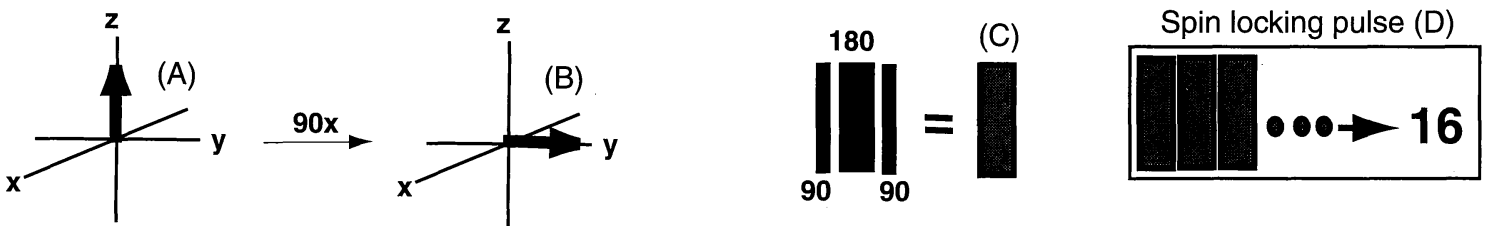

Spin locking pulse consists of 16 repetitive pulse sequences (D) of 90,180 and 90 degree pulse set (C). After 90 degree pulse toward (A) state, spin locking pulse toward (B) state affords Homonuclear Hartman-Hahn (TOCSY) spectrum.

Mlevスピンロックパルスは、90、180、90 度パルス (C) からなるパルスセットを 16 回 (D) 繰り返し，混合時間の間出力 することである。90度パルスにより励起された (B) の磁化に対してスピンロックパルスを照射すると，y軸上において カップリングによる磁化移動が起こりHomonuclear Hartman-Hahn (HOHAHA)またはTotal Correlation Spectroscopy (TOCSY)スペクトルが得られる。

\section{Pulse calibration}

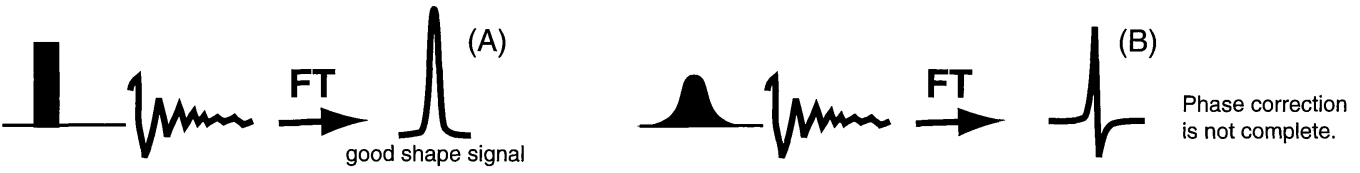

Rectangular pulses have a phase which is adjusted to the receiver phase. Therefore good shape signal $(A)$ is obtained by fourier transformation. However, substitution of the rectangular pulse by shaped pulse whose phase is different to the rectangular pulse affords an incomplete signal (B). Therefore, phase correction of shaped pulse toward receiver phase should be essential in order to have a good shape signal.

矩形波ハードパルスは、レシーバーに合わせた位相がある。したがって、フーリエ変換をして吸収形のシグナルを 得ることができる $(\mathrm{A})$ 。しかし、矩形波ハードパルスをシェープドパルスに変えると A とは異なる位相を伴なうシグナルを 与えてしまう(B)。そのため、シェープドパルスをハードパルスと同位相に補正して測定すれば、吸収形シグナルを 得ることができる。

\section{Gradient pulse}

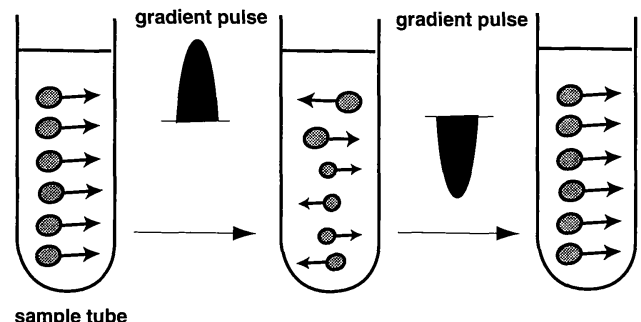

(A)

(B)

(C)
Gradient puilse enables magnetizations excited to spoil (B). Second gradient pulses with the same negative power can refocus the spoiled magnetization (C). The magnetization of $(B)$ state can not be observed as a FID signal due to being spoiled, but (C) state can afford an FID signal. Therefore, we can divide into desired- and undesired-signals by this gradient pulses. The magnetizations along the Z-axis are not affected by the Z-gradient pulse.

グラジュエントパルスは、励起した磁化の状態を壊すことが

できる(B)。そして、反対符号で強度は同じグラジュエントパルスを 与えると、再度磁化は収束する。(B)の状態の FID シグナルは、 磁化が分散しているためにほとんど“0”であるが、(C)のように 再度収束すると良好な FID を得ることができる。このようにして必要な 磁化とそうでない磁化をグラジュエントパルスによって分離することが できる。Z 軸に沿った磁化は Z 軸方向のグラジュエントパルスでは 影響を受けない。 


\section{Phase sensitive NOESY}

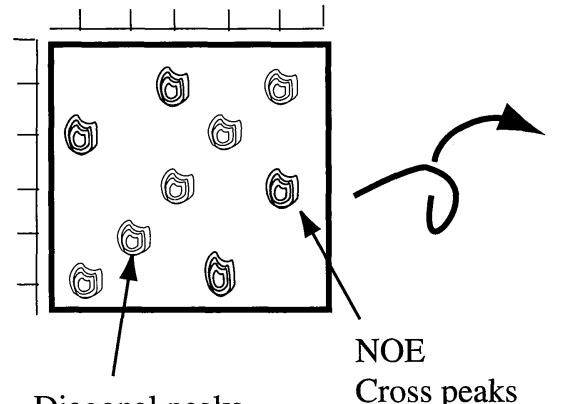

Diagonal peaks

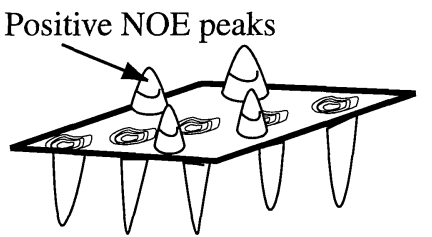

Negative diagonal peaks

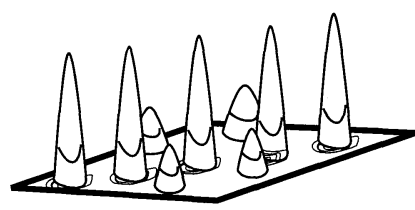

Magnitude calculation

Phase sensitive NOESY shows NOE signals with signs such as positive and negative. When NOE signals are observed at the opposite panel compared to the diagonal peaks, the NOE signals are assigned as a positive. Hence, magnitude mode fourier transformation of the 2D-NOESY loses the phase information. phase sensitive NOESYスペクトルは、正と負の符号を区別してNOE シグナルを表示する。NOE シグナルが対角シグナル と反対側に観測されると、これを正という。さらに、フーリエ変換をマグニチュードモード（全て同一平面に表示する）で おこなうとフェーズ情報は失われてしまう。

\section{Molecular correlation time $\left(\tau_{c}\right)$}

Molecular correlation time means the duration of reorientation of the magnetization. After magnetization of an atom $(I=1 / 2)$ in a molecular move to somewhere in the NMR tube, the magnetization of the molecular may reorients to the first direction. This period is known as molecular correlation time. In the case of small molecular, molecular correlation times is relatively small which means flexible molecule. On the other hand, with large molecular, molecular correlation times is large.

分子相関時間とは、磁化が再度同じ方向へ配列するまでの時間をいう。分子中のスピンが $1 / 2$ の核の磁化が、サンプル管 中のどこかへ移動しても、また最初の位置に戻ってくる。その時間を分子相関時間という。低分子の場合は、この時間が短い。 言い換えると、運動性が高い分子である。一方、高分子の場合は、分子相関時間が長い。

\section{Larmor frequency $(\omega)$}

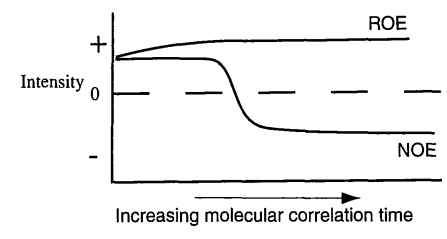

The nuclei precess around the magnetic field axis at a speed called the Larmor frequency.

Hydrogen resonates at $500.13 \mathrm{MHz}$ under the 11.3 Tesra. The carbon atom is $125 \mathrm{MHz}$. The $\omega \tau_{c}$ is close to 1 , NOE signal is almost " 0 ". However, when the values are $\omega \tau_{c}<1$ and $\omega \tau_{c}>1$, NOE values are positive and negative sign, respectively. ROE is always a positive value.

核は、静磁場方向の周りを、Larmor frequencyと呼ばれる一定の速度で歳差運動する。例えば、11.3テスラ の磁場の中では、プロトンは、 $500.13 \mathrm{MHz}$ 、炭素は $125 \mathrm{MHz}$ である。 $\omega \tau_{\mathrm{c}}$ 值がほとんど 1 の場合は、NOE は観測できない。 しかし、その数值は 1 以上あるいは 1 以下の場合は、それぞれ正および負の NOE として観測される。ROE は常に正の シグナルである。

\section{Rotating frame}

The nuclei rotate. If an observer could rotate around the nuclei at the same speed, the observer would see that the nuclei are not in rotation. Therefore the observer can define the coordinate known as a rotating frame (A). 分子中の原子は、回転している。観測者がその原子の回転速度と同じスピードで原子の周りを周回すれば、原子は 回転していないように見える。その結果、回転座標系と呼ばれる座標を決めることができる(A)。

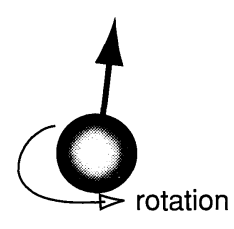

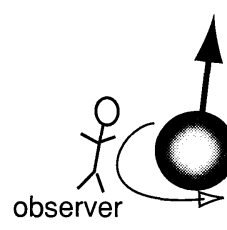

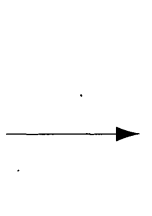




\section{Appendix-3}

\section{Phase cycle}

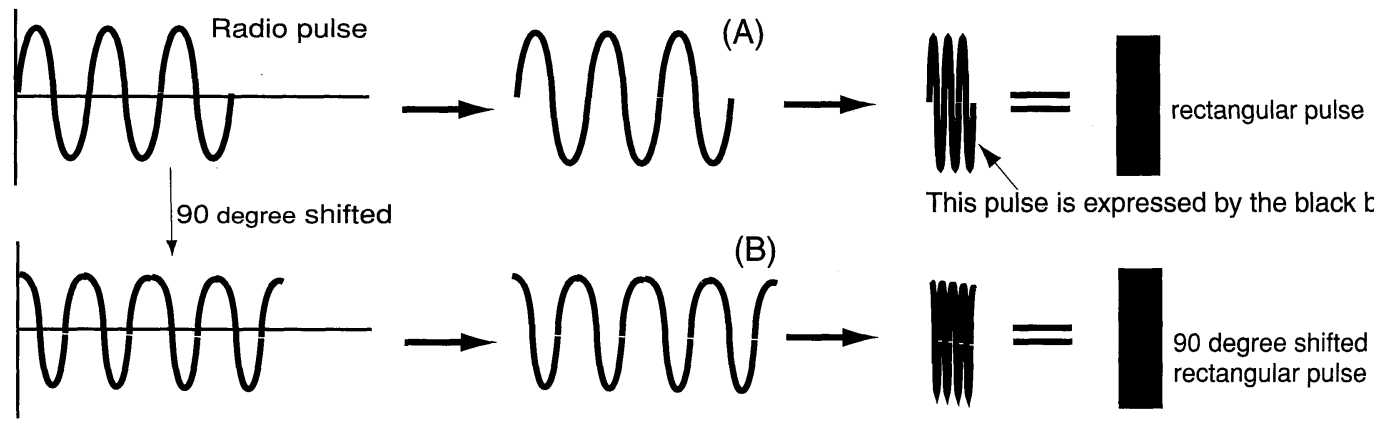

The pulse consists of radio frequency with a phase as shown above. The phase of $(B)$ pulse is shifted by 90 degrees compared to the (A) pulse. In order to decrease the artifact signal in the NMR spectrum, the phase of the pulse is shifted by several times during scanning (CYCLOP).

パルスは上図に示したように位相をもったラジオ波である。(B) パルスの位相は (A) に比べ 90 度 ずれている。NMRスペクトル中の人工的な不要なシグナルを消去するために、スキャンをする際 パルスの位相を変えながら測定する (CYCLOP法)。

\section{Coherence diagram and coherence orders}

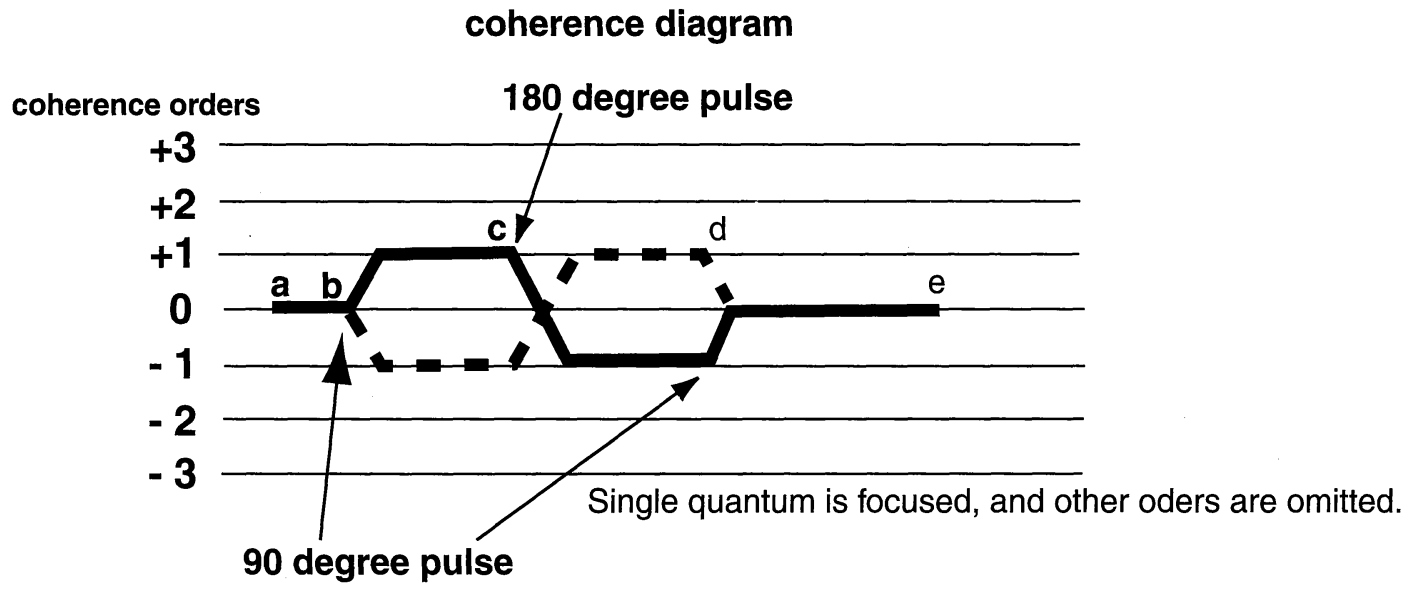

Coherence orders are up and down by the 90 degree pulse, and these orders are useful for analysis of coherence selection which means selection of desired magnetization of nuclei. When the 90 degree pulse is examined, coherence order is up and down as shown above (b). Single and other orders except for "0-order" are reversed by the 180 degree pulse (c). The "0-order state" is not affected by either the 180 degree pulse or the gradient pulse. Over single quantum orders are spoiled by gradient pulse.

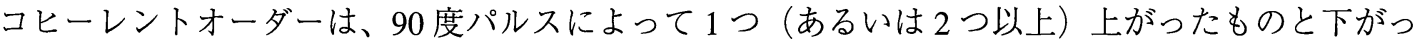
たものを生じる。このオーダーは必要な磁化を選択するコヒーレンスセレクションの解析に有用 である。90 度パルスの場合は、(b) のように上がったり下がったりする。0 量子を除く、1 量子、 および他の量子数のオーダーは、180 度パルスによって反転する (c)。0 量子の状態は 180 度パルス およびグラジュエントパルスの影響を受けない。すなわち、0 量子以外はグラジュエントパルスに よってスポイルされる。 


\section{Appendix-4}

\section{Coherence selection by pulsed field gradient and by phase cycling}
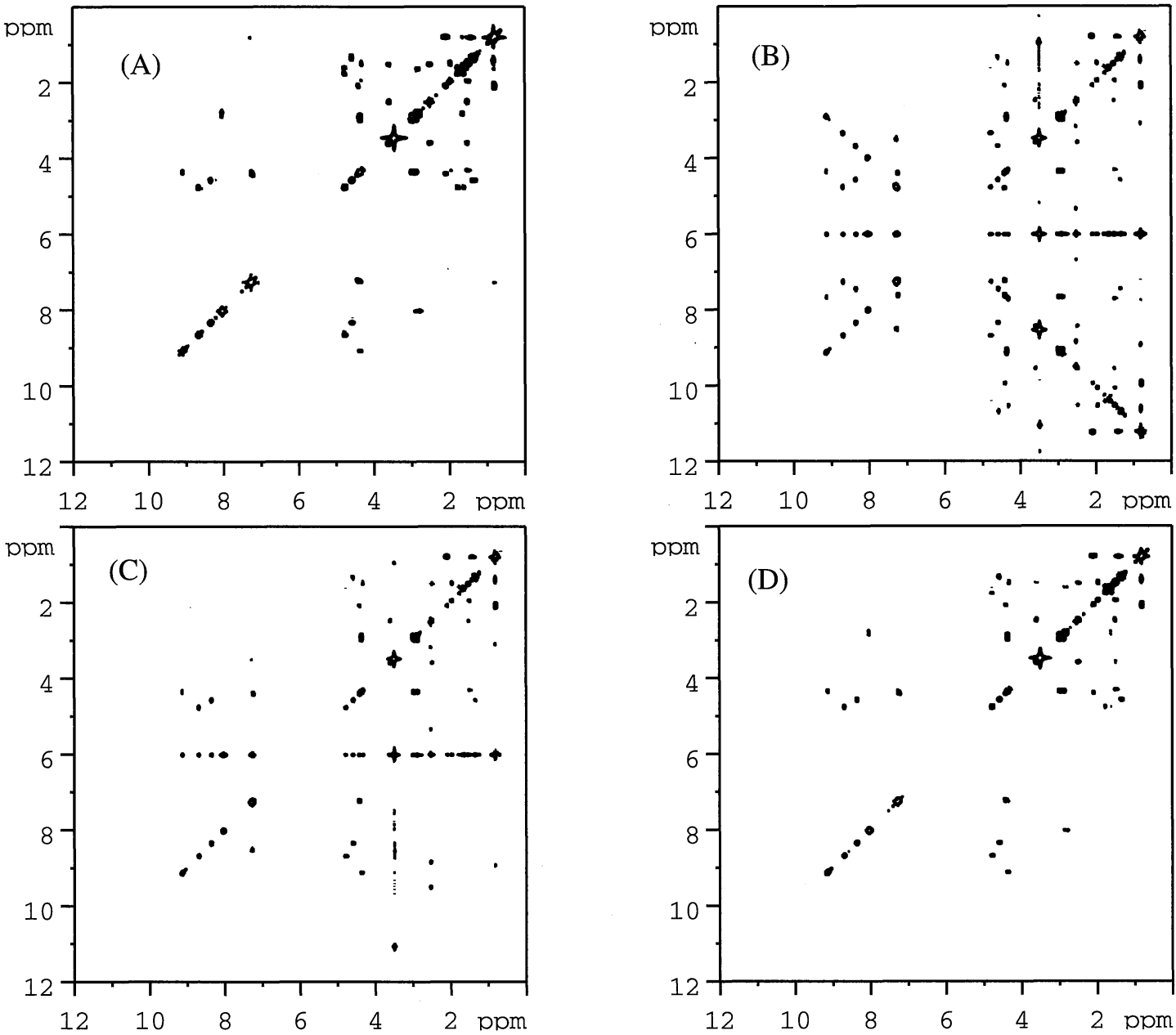

(A) Coherence selection by pulsed field gradient with 1-scanning experiment.

(B), (C) and (D) Coherence selection by phase cycling with 1-, 2- and 4-scanning experiment, respectively. In (B), both anti-diagonal peak and axial peak in $\mathrm{t} 1$ are not suppressed. In (C), anti-diagonal peak is suppressed, but axial peak in $\mathrm{t} 1$ is not suppressed. In (D), both anti-diagonal peak and axial peak in $\mathrm{t} 1$ are suppressed. Finally, 4-scanning is essential to achieve the coherence selection by phase cycling for COSY spectrum.

(A) 1 回スキャンによるパルスフィールドグラジュエントを用いたコヒーレンスセレクション。(B)、(C) および (D) は、 フェーズサイクルを用いた、1 回、2 回、4 回のスキャンによるコヒーレンスセレクションである。(B)のスペクトルでは、 対角ピークとクロスピークがt1方向に対象に観測されてしまう。(C)のスペクトルでは、対角ピークの $\mathrm{t} 1$ 方向への観測は きえているが、依然クロスピークは消えていない。(D)では、 $\mathrm{t} 1$ 方向への対角ピーク、クロスピークは消えている。 このようにフェーズサイクル法を用いてコヒーレンスセレクションをするには、最低 4 回のスキャンが必要である。 


\section{Profile of the Authors}

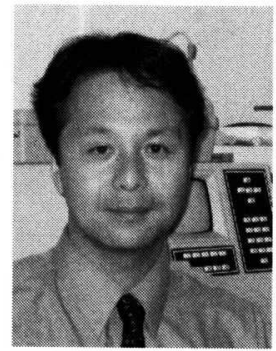

Yasuhiro Kajihara was born in Yamaguchi in 1965. He received Bachelor of Science (1988) from Faculty of Engineering, the Kanagawa University and Ph.D. (1993) from Department of Life Science, Tokyo Institute of Technology. After spending two years at Japan Tobacco Inc. as a postdoctoral research fellow. He became assistant professor at Faculty of Science, Yokohama City University in 1995 and promoted as an Associate Professor in 2001. His major research interests are chemical and enzymatic synthesis of oligosaccharides, glycopeptides and its structural analysis by NMR.

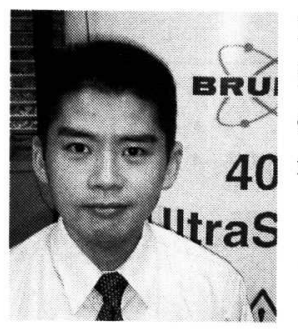

Hajime Sato was born in Shizuoka Pref. in 1967. He received Master of Engineering from Graduate School of Engineering, Yokohama National University in 1993. And he joined to the NMR Application division, Bruker Co., Ltd. in 1993. His job in the company is a customer support and his research is a pulse programming for NMR of oligosaccharides. 